\title{
Evidence from the northern Red Sea on the transition from continental to oceanic rifting
}

\author{
JAMES R. COCHRAN and FERNANDO MARTINEZ \\ Lamont-Doherty Geological Observatory of Columbia University, Palisades, NY 10964 (U.S.A.)
}

(Received April 20, 1987; revised version accepted January 4, 1988)

\begin{abstract}
Cochran, J.R. and Martinez, F., 1988. Evidence from the northern Red Sea on the transition from continental to oceanic rifting. In: X. Le Pichon and J.R. Cochran (Editors), The Gulf of Suez and Red Sea Rifting. Tectonopnysics, 153: 25-53.

The northern Red Sea is an active rift in the last stages of continental rifting which is beginning to undergo the transition to oceanic seafloor spreading. The rift can be divided into two distinct regions. The "marginal areas" consist of a series of bathymetric terraces, and as indicated by geophysical data, are underlain by a series of rotated fault blocks. The "axial depression", which forms the axis of deep water, is a continuous region 10 to $25 \mathrm{~km}$ wide near the center of the sea which is characterized by high heat flow, a large gravity minimum and very deformed sediments. Both regions are divided along strike into segments roughly $60 \mathrm{~km}$ long by cross-trending transfer zones. The presently active tectonics are characterized by the concentration of extension and deformation in the axial depression and by the emplacement of a number of large intrusions. The intrusions occur at distinct sites located at the intersection of transfer zones with the faults bounding the rotated blocks in the marginal areas, and at deeps located in the axial depression halfway between transfer zones.

Although extension is becoming concentrated in the axial depression, geophysical data imply that at least the upper few kilometers of the crust in that region consists of non-magnetic "continental type" material and that this ca apace has been ruptured by large intrusions only at the deeps. A wide range of crustal seismic velocities has been observed in the northern Red Sea, including velocities normally associated with oceanic crust. The velocity variations appear spatially related to corresponding large variations in basement rock type observed on shore in the Eastern De;ert of Egypt.

The northern Red Sea is in an intermediate stage between a continental rift valley and a young ocean basin and delineation of its structure and tectonics allows a model to be developed for the evolution of a rifted continental margin. Rifting starts in a series of linked half grabens $50-60 \mathrm{~km}$ long and formed over detachment surfaces which probably penetrate no deeper than the mid or lower crust. This style of rifting can accommodate at least the amc unt of extension represented by the Gulf of Suez $(35 \mathrm{~km})$. At some greater amount of extension, the rift acquires a more symmetric shape, probably through the development of antithetically faulted blocks in the hanging wall. Extension in this stage is still distributed throughout the rift and is accommodated in the upper crust by rotation of fault bloxks. At the stage represented by the northern Red Sea, extension becomes concentrated in an axial depression and begins to be partially accommodated by large intrusions which form deeps. The position of the deeps is controlled by the transfer zones established in the earliest stages of rifting. With further extension, the deeps serve as nucleation points that develop into small, discrete cells of seafloor spreading. These cells grow and coalesce to form a continuous mid-ocean ridge spreading center such as is found in the southern Red Sea.
\end{abstract}

\section{Introduction}

Observations of "passive" or "Atlantic-type" continental margins over the past ten years have delineated a set of features common to most margins, and the basic structural geometry of rifted margins is reasonably well understood (Fig. 1). In approaching a continental margin from the land, coastal plain sediments are found to thicken slowly toward a "hinge zone", where the basement falls 


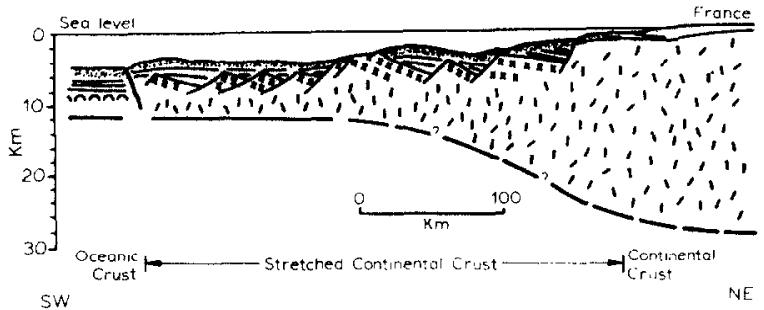

Fig. 1. Schematic cross section across the continental margin of the northern Bay of Biscay, based on multichannel reflection and refraction data. The profile shows typical features of rifted continental margins including a "hinge zone" where the crust thins from typical continental thicknesses of greater than 30 $\mathrm{km}$ to less than $20 \mathrm{~km}$, a region of tilted fault blocks and thin crust, and a sharp transition between the fault blocks and oceanic crust. After Montadert et al. (1979) away in a series of faults and flexures (Jansa and Wade, 1975). The greatest subsidence and sediment accumulation is found seaward of the hinge zone beneath the continental shelf or upper continental rise depending on sediment supply (Watts, 1981). The hinge zone appears to be the major structural boundary marking the edge of "normal" continental crust. Seismic refraction results (for example, Keen and Barrett, 1981) and gravity and geoid models (Watts and Steckler, 1979) show that at the hinge zone the crust thins over a very short distance from typical continental thicknesses of $30-40 \mathrm{~km}$ to about $8-20 \mathrm{~km}$. The position of the shelf edge is controlled primarily by the sediment

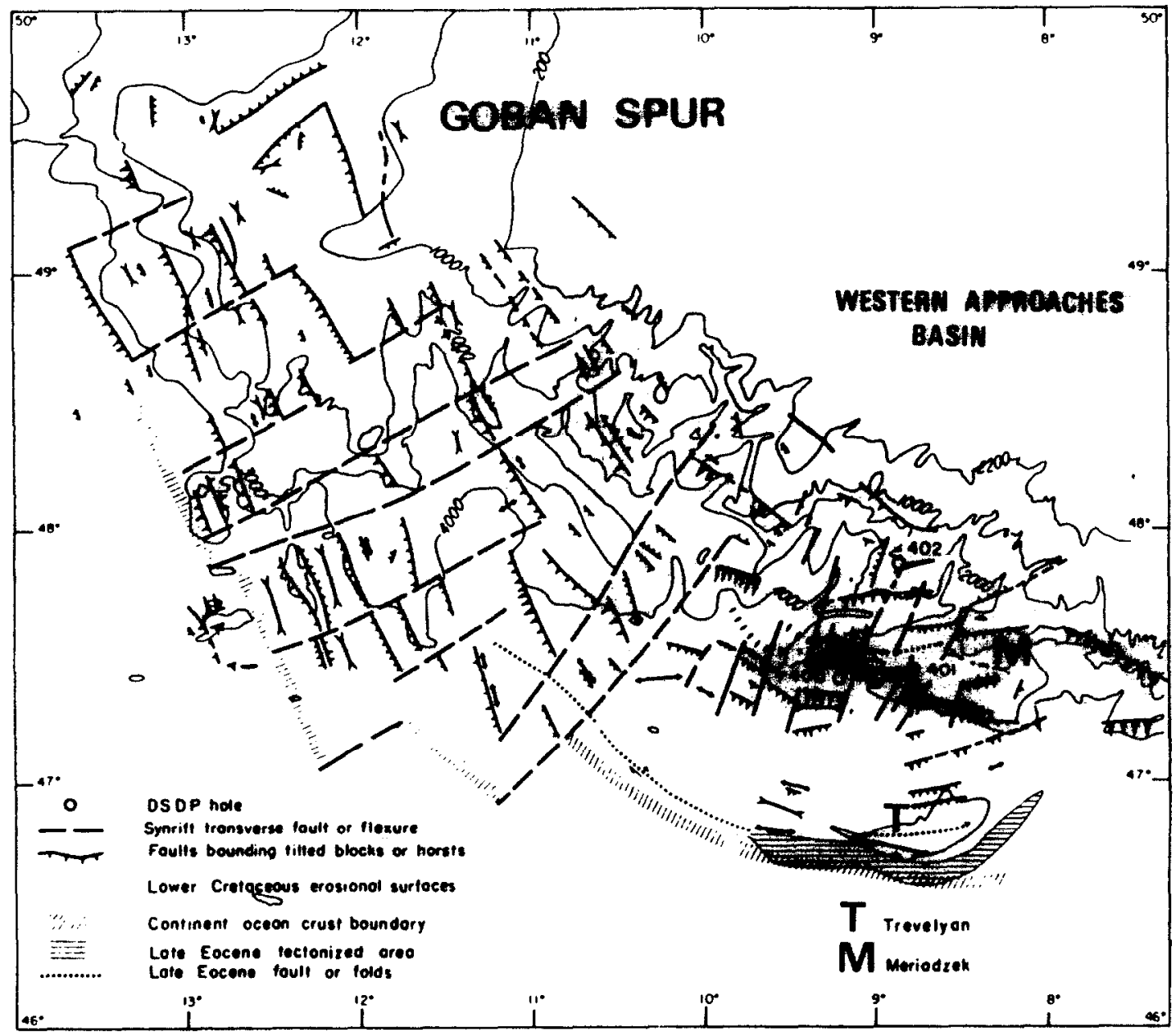

Fig. 2. Structural map of the western portion of the "starved" continental margin of the northern Bay of Biscay. Note segmentation of the margin into a series of fault blocks averaging about $50 \mathrm{~km}$ in length and also the sharp boundary between rifted continental crust and oceanic crust. From Montadert et al. (1979). 
budget. The hinge zone, which is the real tectonic edge of the continent, may be located at any position from under the coastal plain to the edge of the shelf (Watts and Steckler, 1981).

Seaward of the hinge zone another boundary separates a region of transitional crust from true oceanic crust. The structure of the transition zone is probably best known at the sediment-starved margin of the northern Bay of Biscay (e.g. de Charpal et al., 1978; Montadert et al., 1979; Avedik et al., 1982; Ginzburg et al., 1985). The Biscay margin is broken into a series of rotated fault blocks 10-20 km wide and averaging about $50 \mathrm{~km}$ in length along strike (Figs. 1 and 2). Multichannel seismic reflection profiles have been interpreted as indicating that the faults bounding the blocks are listric, curving at depth to form a plane of décollement (de Charpal et al., 1978) which can be interpreted either as a low-angle detachment surface or as representing the boundary between brittle and ductile deformation. The fault blocks become progressively more rotated with greater offset seaward and estimates of the amount of extension implied by this geometry range from $1020 \%$ (Montadert et al,, 1979) to $50-200 \%$ (LePichon and Sibuet, 1981). Seismic refraction studies of the crust beneath the transition region show the presence of a broad region of thinned continental crust (Avedik et al., 1982; Ginzburg et al., 1985; Whitmarsh et al., 1986). In particular, a recent study by Whitmarsh et al. (1986) at the Biscay margin interprets seismic refraction data as showing that a very thin crust of continental origin extends for $100 \mathrm{~km}$ seaward of the hinge zone. In the region of their study, near the ocean-continent boundary, the continental crust is only $4 \mathrm{~km}$ thick.

Where the boundary between the transition zone and oceanic crust can be observed on seismic reflection records, it often appears as a distinct sharp boundary marked by a change in basement type from the hyperbolic reflections associated with oceanic crust to smoother reflections delineating a blocky basement found under the transition zone (Boeuf and Doust, 1975; Montadert et al., 1979). The boundary is sometimes associated with a basement depth discontinuity (Cochran, 1982). The sharp boundary suggests a relatively rapid transition from block faulting and brittle extension (at least at shallow depths) associated with continental rifting to seafloor spreading and extension by massive injection of magma.

The manner in which seafloor spreading is initiated at continental margins and what conditions are necessary to cause the apparently rapid change in extensional mechanism are not well understood. Because there is apparently an abrupt and probably rapid change in the mode of extension, the location and manner in which seafloor generation begins may be controlled by the pre-seafloor spreading structures and processes. Thus, to understand the initiation of spreading, it is necessary to understand the nature of the rifting tectonics prior to and during the transition and the manner in which the rift structures and faultirg interact with the nascent mid-ocean ridge. However, it is also not well understood how the structure observed in continental rifts, which consists of a complex series of overlapping, asymmetric half grabens (Ebinger et al., 1984; Bosworth, 1985: Bosworth et al., 1986; Rosendahl, 1987), evolves into the structures observed at continental margins (Figs. 1 and 2). Neither is it well understood how and under what conditions seafloor spreading begins.

The northern Red Sea presents a unique opportunity to study the transition from continental to oceanic rifting and the establishment of a midocean ridge spreading center at a continental margin because it is presently undergoing that process. Major rifting of the continental lithosphere began in the Red Sea rift near the Oligocene-Miocene boundary and organized seafloor spreading appears to have begun about 5 m.y.B.P. in the southern Red Sea. The Red Sea spreading center becomes younger to the north (Roeser, 1975) and passes into a transition zone located between $20^{\circ} \mathrm{N}$ and $23^{\circ} \mathrm{N}$ (Fig. 3) made up of small, isolated seafloor spreading cells (Cochran, 1983: Pautot, 1983; Bonatti et al., 1984; Bonatti, 1985). There is no evidence of a mid-cicean ridge in the northern $500 \mathrm{~km}$ of the Red Sea and this region appears to still be undergoing late stage continental rifting (Cochran, 1983; Martinez and Cochran, 1988).

The purpose of this paper is to describe the 


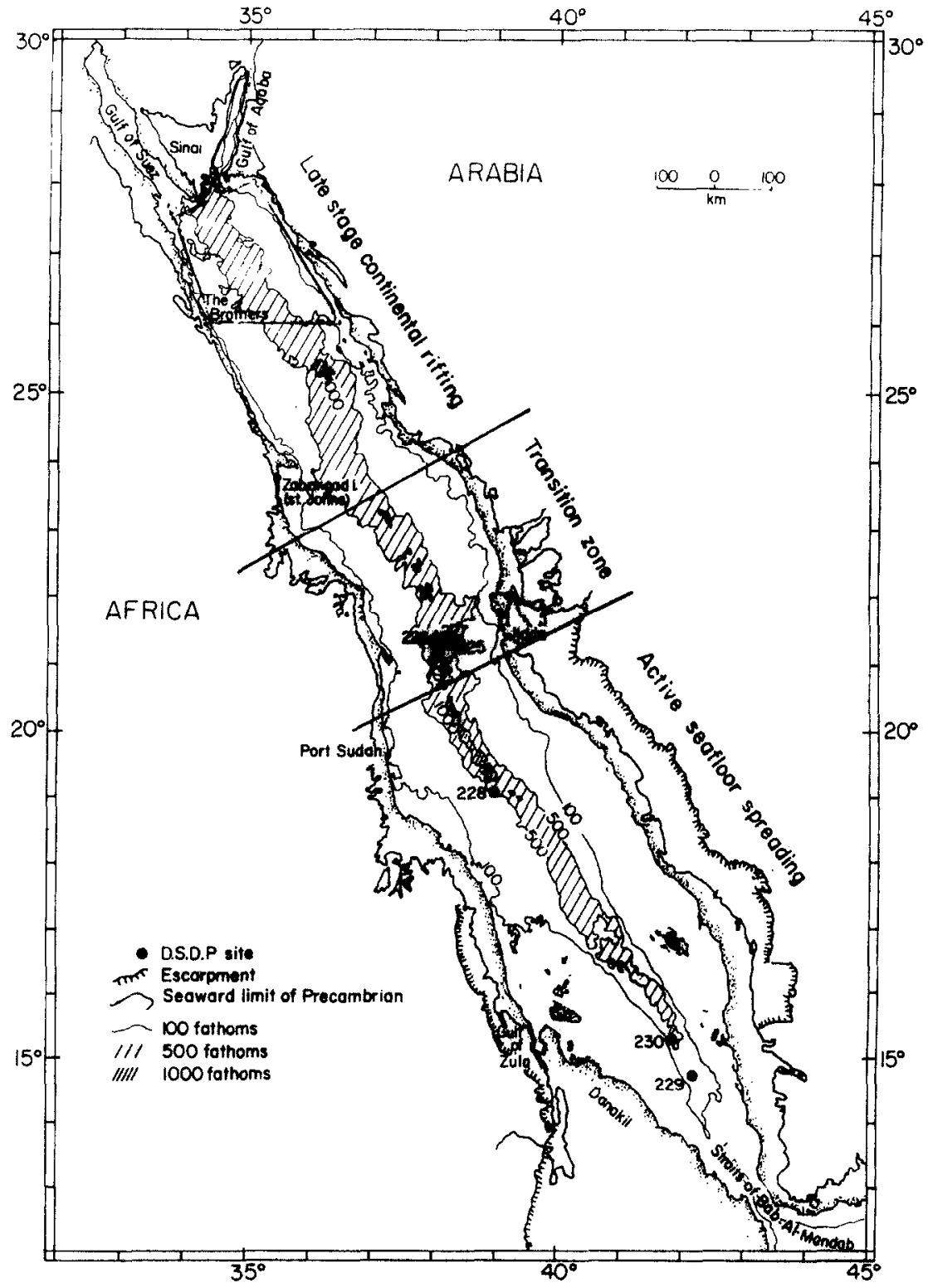

Fig. 3. Location map showing division of the Red Sea into three zones in different stages of rifting. Field area in the northern Red Sea north of $26^{\circ} \mathrm{N}$ is outlined.

structure and tectonics of the northern Red Sea north of $26^{\circ} \mathrm{N}$ and to use these observations as a base for developing a model for the evolution from continental to oceanic rifting and the devel- opment of an organized spreading center. The description of the structure is based primarily on data presented in Martinez and Cochran (1988), where it is more fully documented and discussed.

Fig. 4. Bathymetric map of the northern Red Sea in corrected meters contoured at $100 \mathrm{~m}$ intervals. Fine dots indicate location of data. Data was supplemented in areas of poor coverage by SeaBeam bathymetry presented by Pautot et al. (1986). Opposing sets of brackets indicate locations of transfer zones. Solid lines show locations of geophysical profiles presented in Fig. 5 . 


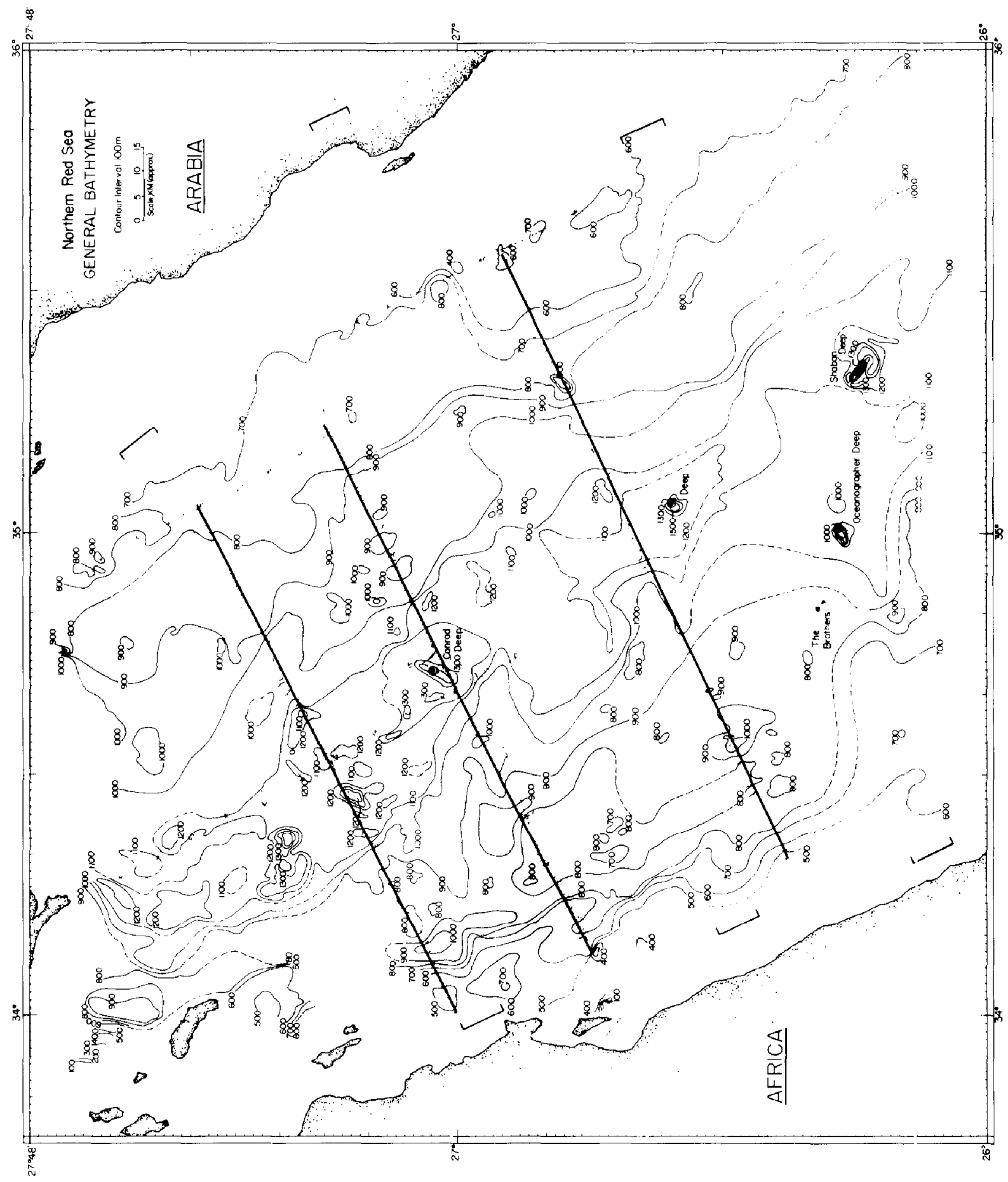


The emphasis in this study will be on the implications of those observations.

\section{Structure of the northern Red Sea}

The northern Red Sea consists of narrow marginal shelves and a broad main trough. The main trough can be divided into two distinct tectonic provinces, referred to as the "marginal areas" (although they actually occupy most of the region) and the "axial depression".

The bathymetry of the marginal areas forms a series of terraces or levels $20-30 \mathrm{~km}$ wide which are generally at depths of about $500,750 \mathrm{~m}$ and $900 \mathrm{~m}$ (Figs. 4 and 5). These terraces are often separated by steep escarpments which appear in many cases, particularly on the western side, to be faulted. The terraces have rough irregular surfaces with local relief which may vary $100 \mathrm{~m}$ in 1 to 2 $\mathrm{km}$.

Free-air gravity anomaly highs are persistently located on the seaward edges of the bathymetric terraces (Fig. 5). A map of the gravity anomalies (Fig. 6) shows that they form a pattern of elongate highs and lows which are oriented subparallel to the NNW-SSE trend of the Red Sea and extend for distances of roughly $50 \mathrm{~km}$ along strike. Quite often there are offsets in the bathymetric contours at locations where the gravity contours are offset or terminate.

Seismic reflection methods have not been able to image the basement anywhere in the marginal areas of the northern Red Sea (P. Miller, pers. commun., 1985; H. Bäcker, pers. commun., 1985).
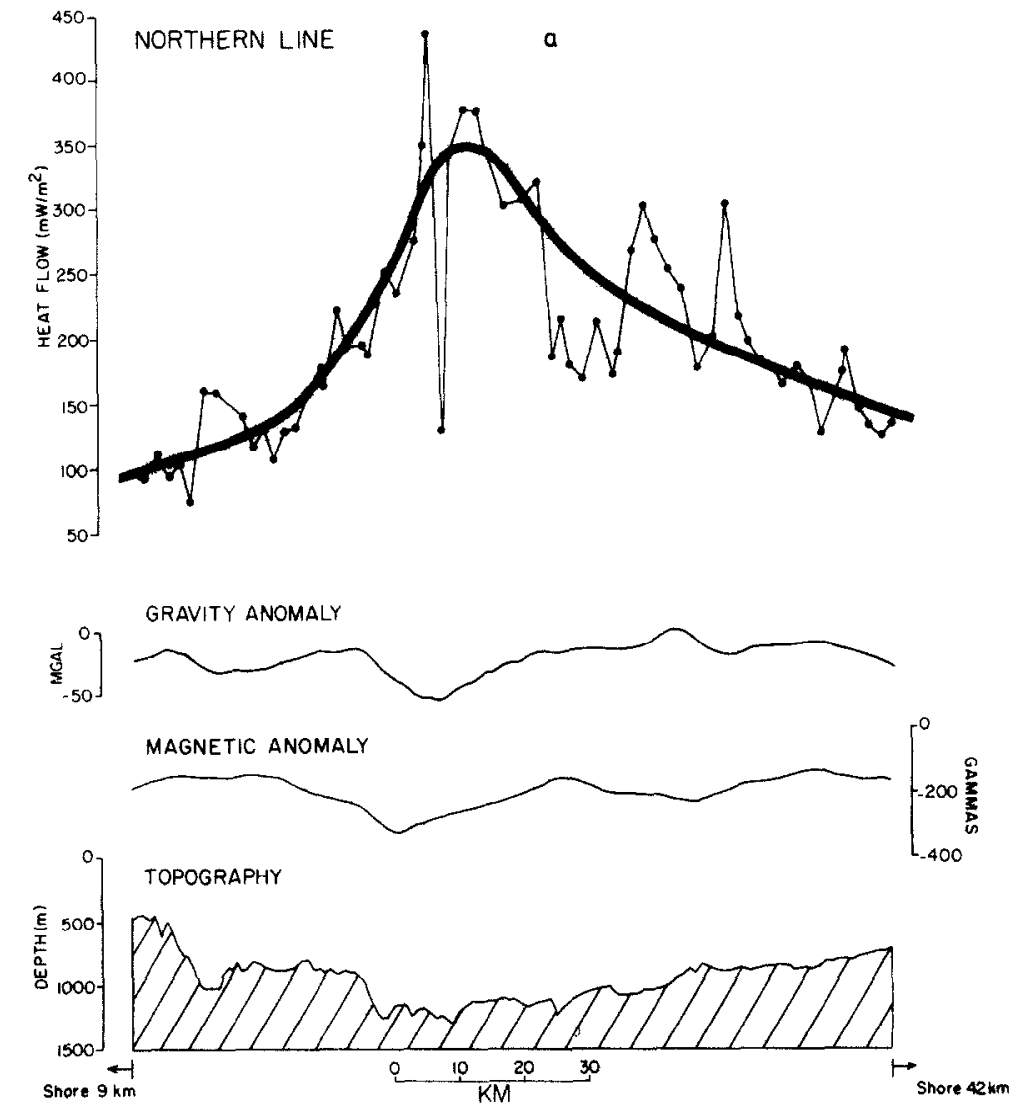

Fig. 5. Bathymetry, free-air gravity, total intensity magnetic anomaly and heat flow profiles along the northern (a), central (b) and southern (c) heat flow lines. All profiles are projected at $\mathrm{N} 60^{\circ} \mathrm{E}$. Heavy line through hent flow data drawn by eye to show general trend of data. The axial depression corresponds to repion with depths greater than about $1100 \mathrm{~m}$. Note correspondence of heat flow high to axial depression even in the northern line (a) where the axial depression is offset to the west. Location of lines is noted in Fig. 4. 
Exxon has run an extensive 48 channel seismic survey in the western half of the Red Sea north of $26^{\circ} \mathrm{N}$ and although they were unable to recognize the basement anywhere, the base of the evaporites could be determined in many places (Barakat and Miller, 1984; Miller and Barakat, this vol.). Martinez and Cochran (1988) digitized the seafloor, top of evaporites and bottom of evaporites following the interpretation of Barakat and Miller (1984) on an Exxon seismic line located almost exactly along the central heat flow line (Fig. 5b) in order to investigate the extent to which relief on those surfaces could explain the observed gravity anomalies. Seismic velocities and densities were chosen to be consistent with nearby wells (Barakat and Miller, 1984) and refraction work (Drake and Girdler, 1964). The results of the gravity model (Fig. 7) showed that the gravity effects of these bodies do not at all reproduce the amplitude or shape of the observed anomalies, which must, therefore, result from relief on a deeper surface, presumably the basement. Thus, the gravity pattern can be interpreted as displaying the basement relief, which Martinez and Cochran (1988) interpreted as a series of tilted fault blocks $20-30 \mathrm{~km}$ across and roughly $60 \mathrm{~km}$ in length.

The elongate gravity highs and lows are terminated or offset along three transverse features which often also offset the topographic con-
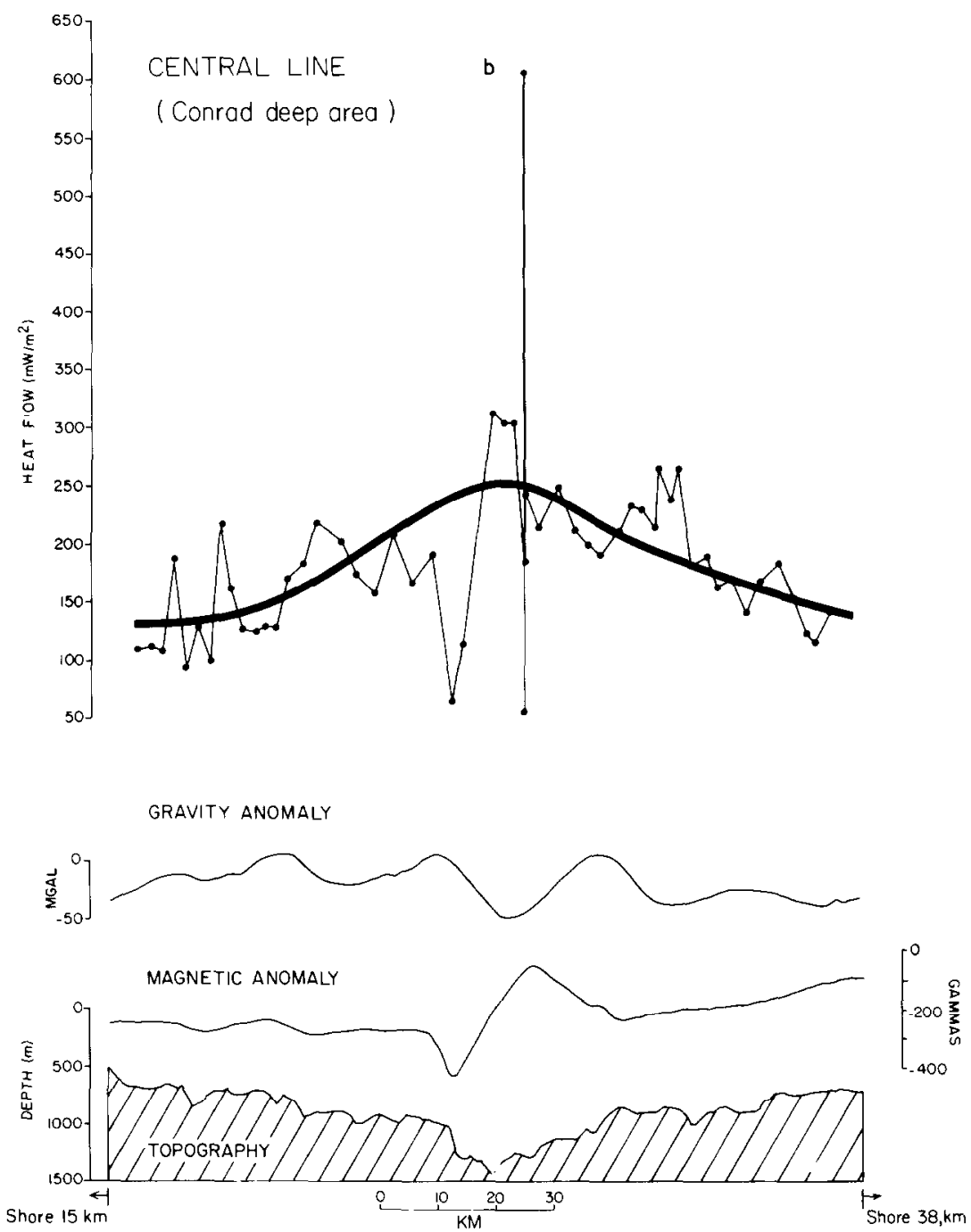

Fig. 5 (continued). 

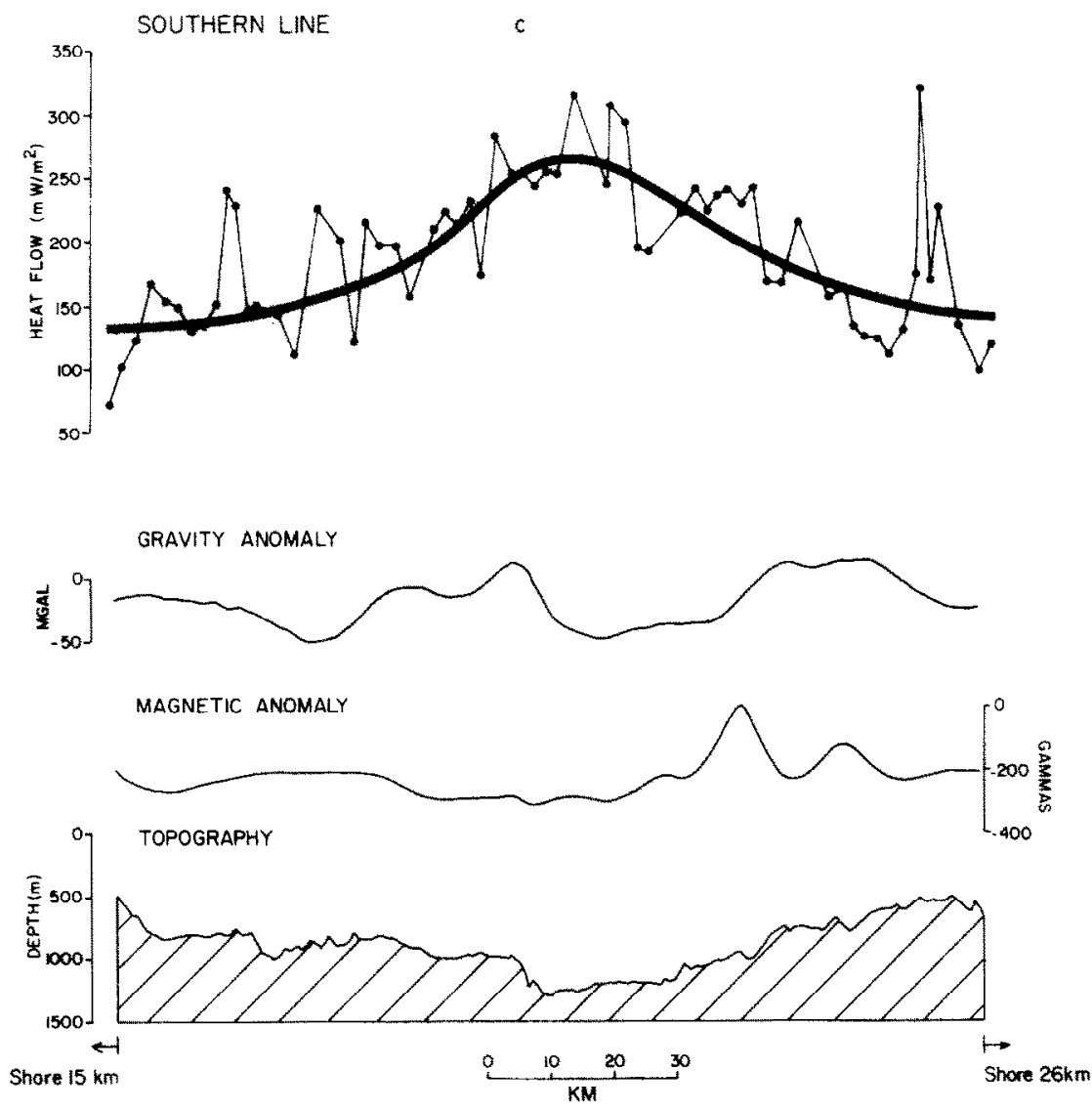

Fig. 5 (continued).

tours. The location of these features which trend about $\mathrm{N} 50^{\circ} \mathrm{E}$ to $\mathrm{N} 60^{\circ} \mathrm{E}$ across the Red Sea is noted on Figs. 4, 6, and 10. The two northern features are both associated with subsurface faulting on two NNW-SSE oriented Exxon seismic lines, although numerous diffractions make the nature of the faulting difficult to determine. They have a surface expression on several SeaBeam crossings as a sinuous trough, 50-150 m deep and several hundred meters wide (Martinez and Cochran, 1988). The southern feature is mapped primarily from the gravity pattern since less geophysical data are available from that region. Further description and documentation of these features is given in Martinez and Cochran (1988).

The transverse features appear to be "transfer zones" which mark the boundary between sets of fault blocks which are behaving independently and they thus serve to accommodate the local differential motion between the blocks. The structure implied for the marginal areas of the northern Red Sea is a series of rotated fault blocks bounded by complex transverse "transfer zones" spaced roughly $60 \mathrm{~km}$ apart. This structure is very similar to that observed seaward of the hinge zone at sediment starved margins such as the Bay of Biscay (Montadert et al., 1979; Avedik et al., 1982; and Figs. 1 and 2). The segmentation of a rift by transfer zones appears to be a fundamental aspect in the development of a continental margin, since it occurs nearly at the inception of continental rifting (Bosworth, 1985) and, as we will argue later, appears to control the nucleation of seafloor spreading.

Fig. 6. Free-air gravity anomalies in the northern Rad Sea contoured at $10 \mathrm{mGal}$ intervals. Fine dots indicate location of data. Opposing sets of brackets indicate location of transfer zones. 


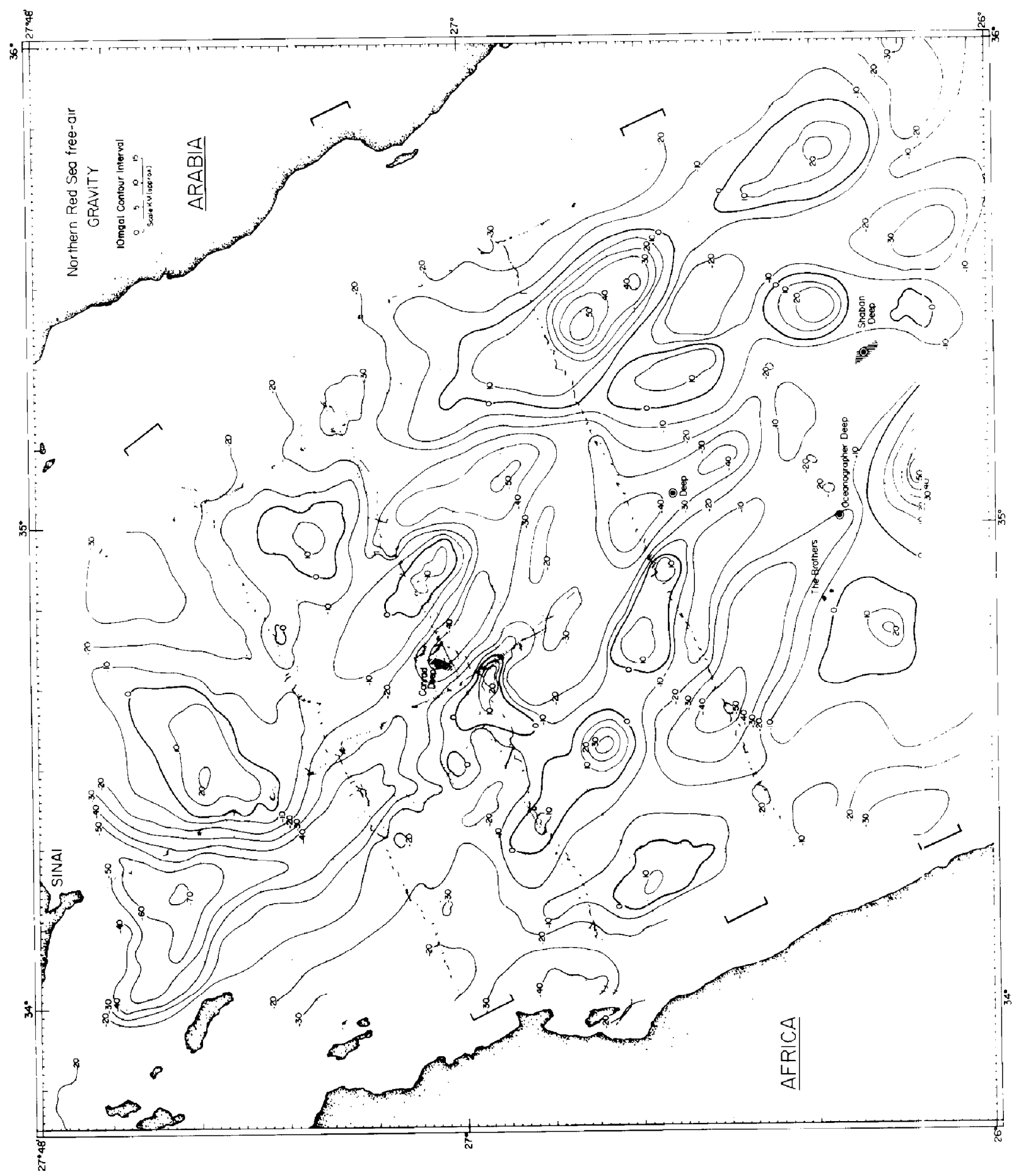


Free-air Gravity Anomalies

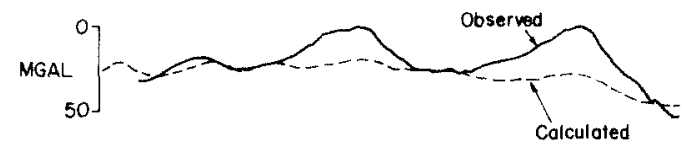

Stratigraphic Section

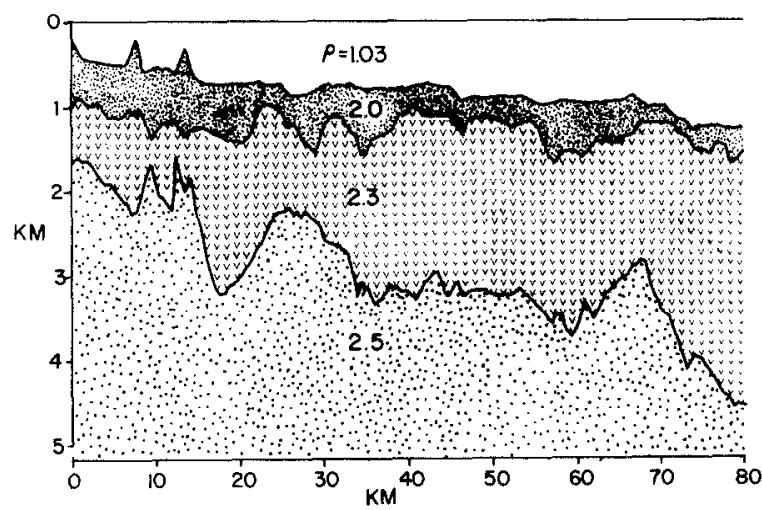

Fig. 7. Gravity model comparing observed gravity anomalies (solid line) to the calculated gravity effect (dashed line) of water (blank), post-evaporite sediments (fine stipple), evaporites (v-pattern) and pre-evaporite sediments (coarse stipple). Bodies were determined from an Exxon multichannel seismic line presented by Barakat and Miller (1984) which was coincident with the "Conrad" gravity line. All bodies were assumed to be two-dimensional. Base of the pre-evaporite sediments was assumed to be flat. Failure of calculated gravity anomalies to match observed anomalies appears to result from relief on the basement-pre-evaporite boundary and justifies use of the gravity anomalies to show relief on this boundary.

A consistent feature of the northern Red Sea is an axis of deeper water, $1100-1250 \mathrm{~m}$ deep and from 10 to $25 \mathrm{~km}$ wide, referred to as the "axial depression" (Cochran et al., 1986). The axial depression differs from the oceanic axial trough of the southern Red Sea in that sedimentary sequences, including Upper Miocene Reflector $S$ (top of evaporites), are continuous across it, lineated high amplitude magnetic anomalies are not present and it is much shallower. The axial depression is often fault bounded (Figs. 8 and 9) and is located near the center of the main trough except at the northernmost part of the Red Sea, where it is shifted to the west across the northern transfer zone and becomes aligned with the Gulf of Suez. It is marked by a consistent free-air gravity low of -30 to $-40 \mathrm{mGal}$ (Figs. 5, and 6) and is the location of the maximum heat flow with values falling off systematically toward the coasts ( $\mathrm{Fig}$. $5)$. The coincidence of the axial depression and heat flow high is true even for the northern heat flow line (Fig. 5a) which is located just north of the northern transfer zone, where the axial depression is considerably offset to the western portion of the Red Sea.

The axial depression is the location of the three deeps that have been identified in the survey area, Conrad Deep, just north of $27^{\circ} \mathrm{N}$ (Cochran et al., 1986), an unnamed deep at $26^{\circ} 36^{\prime} \mathrm{N}$ (Pautot et al., 1986) and Shaban (or Jean Charcot) Deep near $26^{\circ} 15^{\prime} \mathrm{N}$ (Pautot et al., 1984). These are all small northern Red Sea type deeps which are associated with large dipolar magnetic anomalies (Fig. 10) and appear to result from isolated intrusions. A volcanic ridge can be observed in Shaban Deep (Pautot et al., 1984). Cochran et al. (1986) concluded from magnetic and heat flow data that Conrad Deep is associated with recent intrusions into relatively unmagnetized crust. A similar magnetic anomaly pattern is observed over the unnamed deep (Fig. 10).

Conrad Deep and the unnamed deep are located nearly halfway between transfer zones. Shaban Deep is near the southern end of the survey area. However, if transfer zones continue to the south with a spacing similar to that observed in the survey region, then Shaban Deep would also be located halfway between transfer zones. Recent data presented by Guennoc et al. (this vol.) suggests that this may be the case and that another deep appears to be located about $75 \mathrm{~km} \mathrm{SE}$ of Shaban Deep.

The marginal areas and axial depression also differ in the pattern of deformation observed in the sediments. Seismic reflection data (Figs. 8 and 9) show that the marginal areas are affected by a combination of salt tectonics and widely spaced faulting. There are clear examples of recent faulting, such as the small graben on each of the two seismic lines, but in general, the amount of deformation decreases upwards from depth to the seafloor. There are marked discordances in many places with individual reflectors frequently having onlapping terminations on lower ones indicating episodic tectonic activity. 


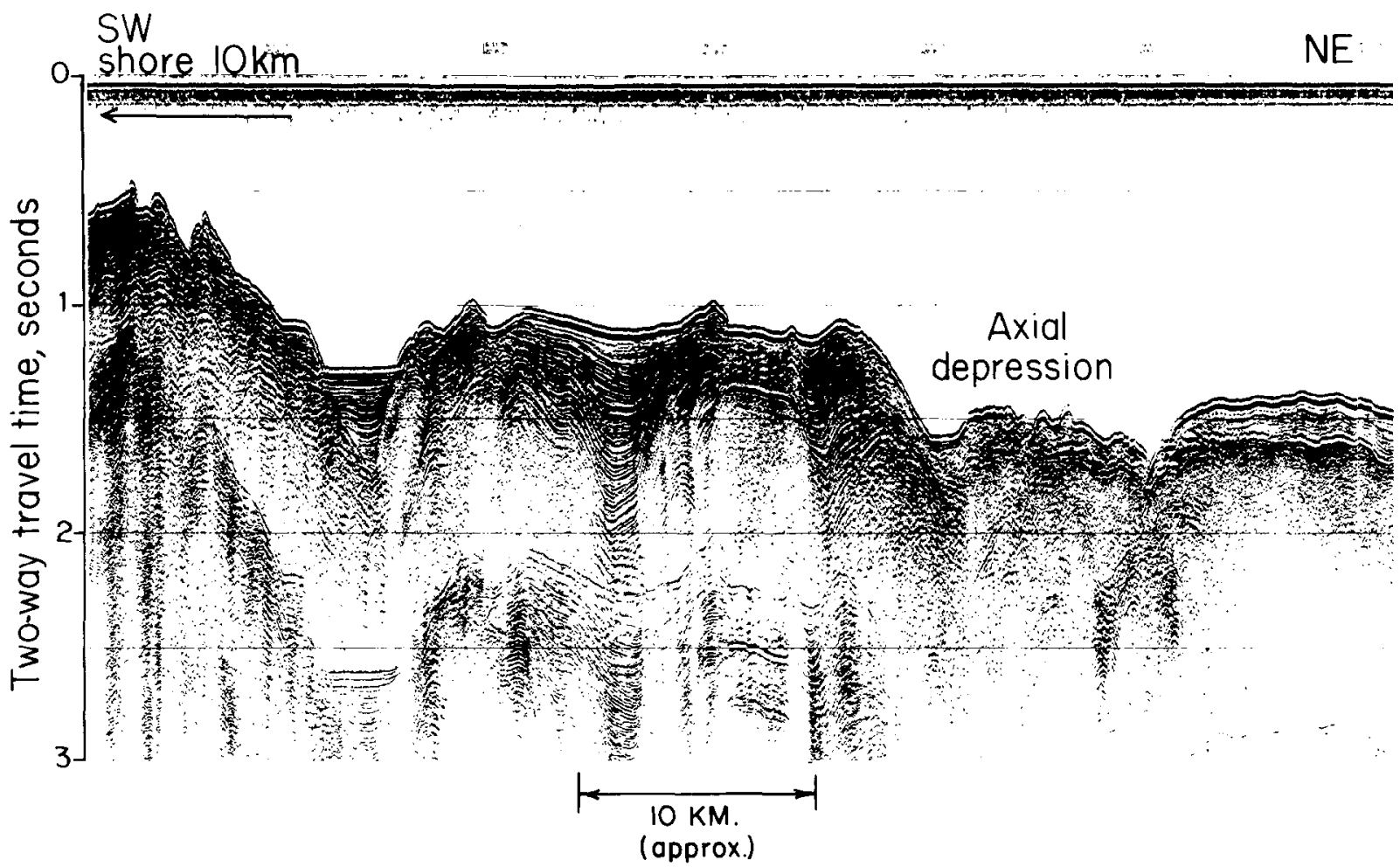

Fig. 8. Water gun seismic reflection line along the western half of the northern heat flow line (Fig. $5 \mathrm{a}$ ). The graben $12 \mathrm{~km} \mathrm{from}$ the southwestern end of the profile and the salt diapirs beneath the block between the graben and the axial depression ars: evidence of continuing deformation on the margins. The shorter wavelength, more intense deformation in the axial depression, including faulting that reaches the surface, suggests, however, that tectonic activity and deformation are now concentrated in the axial re,jion.

In contrast, deformation in the axial depression is more intense and concentrated than in the marginal areas. Seismic lines show intense short wavelength folding and faulting where they cross the axial depression (Figs. 8 and 9). Not only is Reflector $\mathrm{S}$ folded and faulted, but in addition layers above $S$ are more conformable with $S$ in the axial depression than in the marginal areas. Frequently, the seafloor is deformed conformably with $S$ (see Fig. 9) indicating that the deformation is presently active and has not been abating with time. A number of faults can be observed in the axial depression in Fig. 8 which offset the seafloor and Reflector $\mathrm{S}$ by comparable amounts. It thus appears that although faulting and extension do occur throughout the Red Sea rift, they are primarily concentrated in the axial depression. The widespread subsurface deformation suggests that this focusing of the extension is recent and that faulting was previously spread over a wide area.

\section{Nature of the crust underlying the axial depression}

Although the axis of deformation in the northern Red Sea appears to have become narrower with time and extension more focussed in the axial depression, the evaporites have not been ruptured as has happened to the south where a well defined mid-ocean ridge spreading center is present in the axial trough and in the transition zone deeps. In those regions, SeaBeam (Pautot, 1983), sidescan sonar (Garfunkel et al., 1987) and deep tow (Miller et al., 1985; Bicknell et al., 1986) studies show that the morphology and structure of the Red Sea spreading center is similar to that found at slow spreading ridges such as the North Atlantic. This 


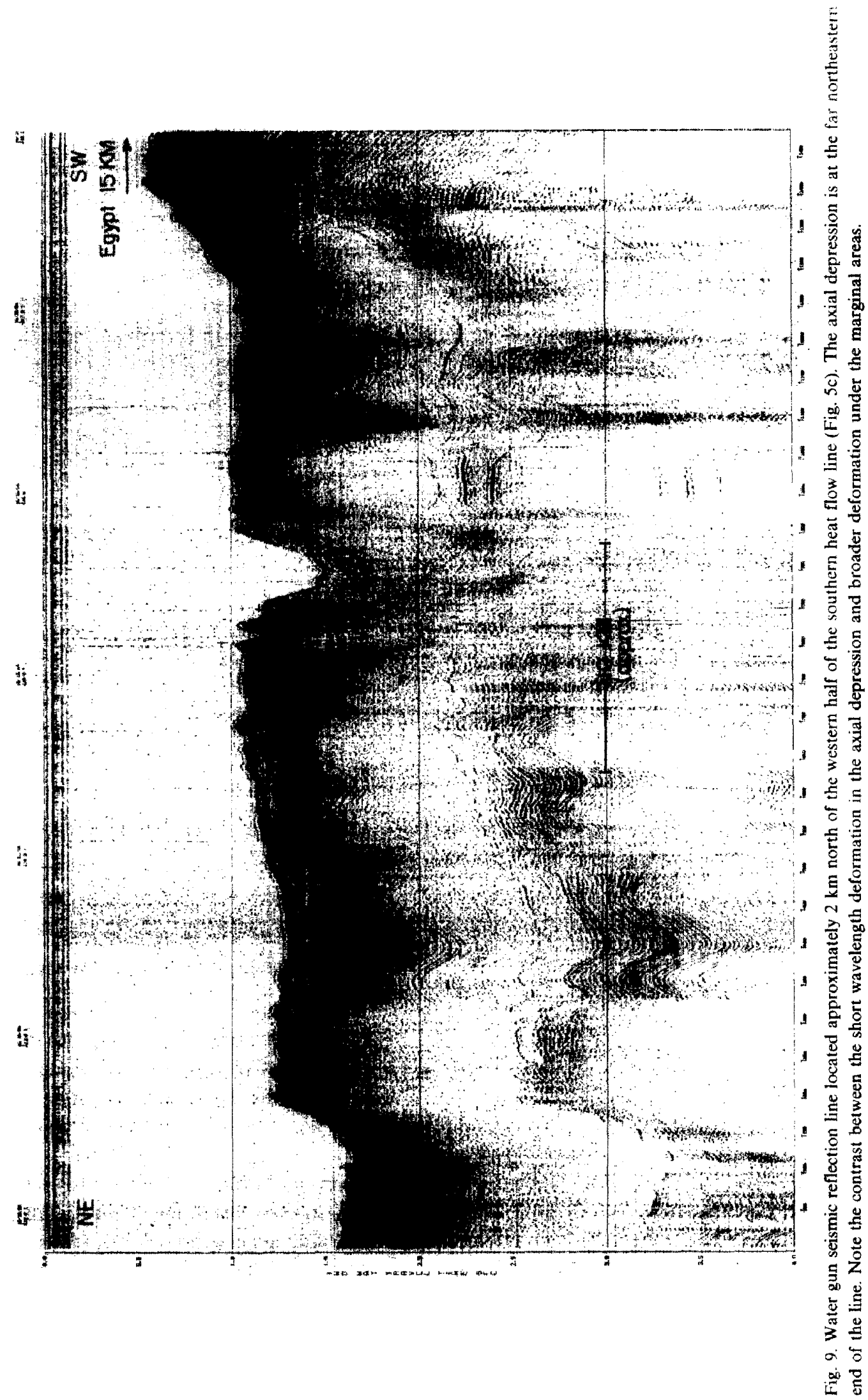


also appears to be the case at Mabahiss Deep, located at $25^{\circ} \mathrm{N}$ in the northern Red Sea, which appears to be an isolated seafloor spreading cell (Pautot et al., 1986). It is characterized by exposed oceanic basement and well developed, lineated magnetic anomalies (Pautot et al., 1986; Guennoc et al., this vol.). A deep-tow magnetics study at $17.5^{\circ} \mathrm{N}$ (Miller et al., 1985) found that the transition between polarities at magnetic reversal boundaries is actually sharper than at the FAMOUS area in the North Atlantic. Thus, although the spreading rates are quite low (total rates of $1.49 \mathrm{~cm} / \mathrm{yr}$ at $17.5^{\circ} \mathrm{N}, 1.06 \mathrm{~cm} / \mathrm{yr}$ at Nereus Deep and $1.0 \mathrm{~cm} / \mathrm{yr}$ at Mabahiss Deep), where there is an organized spreading center in the Red Sea, seafloor generation is proceeding in an orderly manner at a well defined, narrow zone of dike injection. The process has resulted in extension which is concentrated enough to rupture the evaporites, exposing the newly generated oceanic crust.

Other than at Mabahiss Deep, there is no evidence of such a localized spreading center in the northern Red Sea and the primary zone of crustal extension can reasonably be taken to correspond to the region of highly deformed sediments, 10-25 $\mathrm{km}$ wide in the axial depression, although some fraction of the extension may be distributed across the entire rift. The seismic reflection data by itself cannot determine whether the crustal extension in the axial depression is occurring through faulting, diffuse dike injection or some combination of processes.

Some information on the nature of the crust is provided, however, by the combination of magnetics and heat flow data. The magnetic field over the northern Red Sea takes the form of low amplitude, long wavelength variations on which a number of high amplitude, short wavelength anomalies are superimposed (Fig. 10). The local anomalies all take the form of dipole anomaly pairs consistent with the presence of localized normally magnetized sources. The dipolar anomalies over the axial depression are directly related spatially to the three deeps within the axial depression. Cochran et al. (1986) carried out a detailed investigation of magnetics and heat flow data from the vicinity of Conrad Deep and con- cluded that the deep is associated with (and probably results from) a very recent intrusion into relatively unmagnetized material.

The crust could appear nonmagnetic either because it is of a different, less magnetic composition than the intrusions or because it is at too high a temperature for the magnetic minerals to acquire a remanent magnetization. In the latter case, the intrusion must be assumed to be located at a higher level and be largely within the sediments, although this creates severe difficulties because of the large volume of material necessary to produce the observed magnetic anomalies (Cochran et al.. 1986).

Heat flow values in the axial depression average about $250 \mathrm{~mW} / \mathrm{m}^{2}$ (Fig. 5). The sediment section in the axial depression can be estimated from seismic reflection data to consist of about $250 \mathrm{~m}$ of post-evaporite sediment (see Figs. 8 and 9), $3 \mathrm{~km}$ of evaporites (see Fig. 7), and in analogy with the Gulf of Suez about $1 \mathrm{~km}$ of pre-evaporite sediments (M.S. Steckler, pers. commun., 1986). If conductivities of $1.5,5.5$ and $2.5 \mathrm{~W} \mathrm{~m}^{-1}{ }^{\circ} \mathrm{C}^{-1}$ are assumed for the post-evaporite, evaporite and pre-evaporite sediments respectively (Berthelot, 1986), then the increase in temperature through the sediment column is calculated to be $278^{\circ} \mathrm{C}$. The bottom water temperature in the Red Sea is about $21.5^{\circ} \mathrm{C}$ (Cochran et al., 1986), so the temperature calculated at the top of the crust is close to $300^{\circ} \mathrm{C}$. The thermal conductivity of the crustal rocks is about $3 \mathrm{~W} \mathrm{~m}^{-1}{ }^{\circ} \mathrm{C}^{-1}$ (Berthelot, 1986) which implies that the temperature gradient within the crust is about $83^{\circ} \mathrm{C} / \mathrm{km}$ for a heat llow of 250 $\mathrm{mW} / \mathrm{m}^{2}$. Both the temperature at the top of the crust and the gradient within the crust must decrease rapidly away from the axial depression.

Magnetic blocking temperatures are typically in the range of $450-650^{\circ} \mathrm{C}$, so any intrusion reaching the upper several kilometers of the crust should acquire a remanent magnetization. The fact that the magnetic data implies that the crustal rocks have a relatively low magnetization suggests that the upper few kilometers of the crust are not made up of recently intruded oceanic type material. Thus, while the lower part of the crust could be extending through dike injection, it can be argued that at least a carapace of continental type crust 


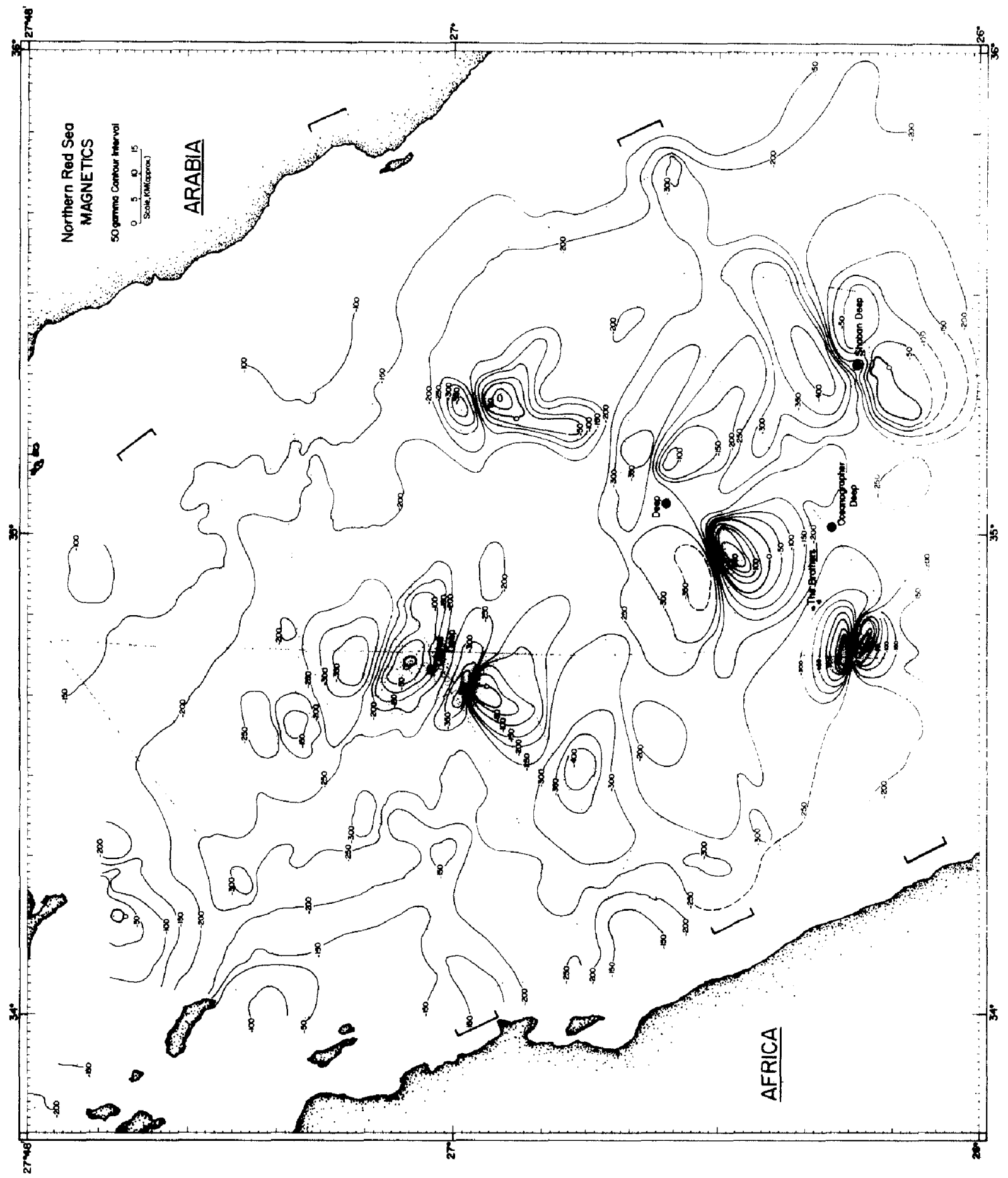




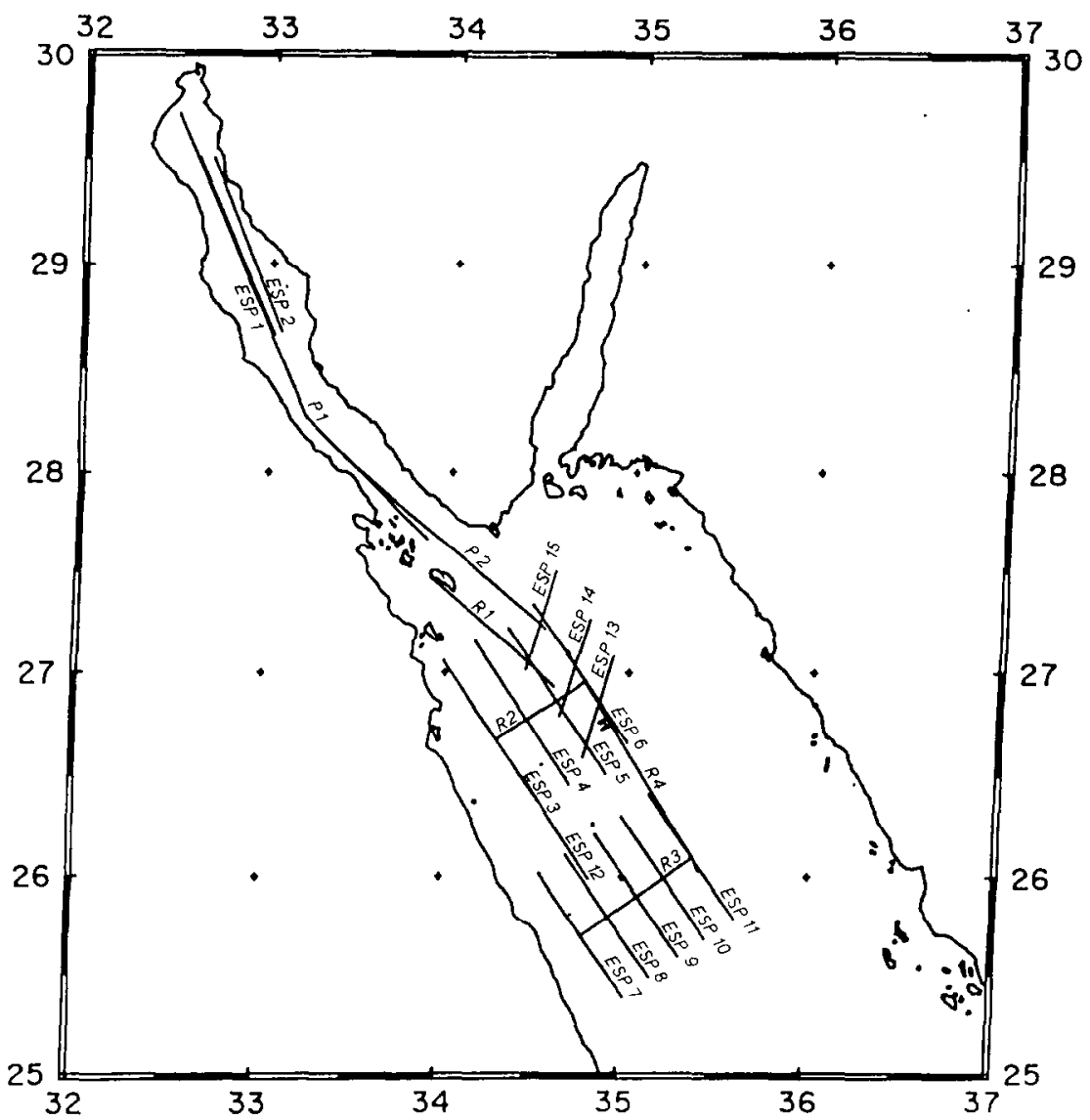

Fig. 11. Map of the northern Red Sea showing location of "Minos Expedition" seismic experiments reported by Gauli:r et al. (this vol.). (From Gaulier et al., this vol.)

must remain in the axial depression. Even if an extremely high value such as $300 \mathrm{~mW} / \mathrm{m}^{2}$ is adopted for the average heat flow in the axial depression, the conclusion remains that the upper portion of the crust would have acquired a magnetization if made up of oceanic type material and that the amplitude of the magnetic anomalies at the deeps would be less than observed.

These conclusions, based on magnetics and geothermal data, appear to be supported by recent seismic work reported by Gaulier et al. (this vol.). Their ESP 14* (Fig. 11) is centered over Conrad

$\overline{* \mathrm{ESP}=}$ expanding spread profile.
Deep. That seismic profile is interpreted as showing a $4 \mathrm{~km}$ thick sedimentary section above a 9.25 $\mathrm{km}$ thick crust consisting of layers with seismic velocities of 5.6, 6.4-6.6 and $7.3 \mathrm{~km} / \mathrm{s}$ (Gaulier et al., this vol.). This structure is in contrast with other nearby ESPs also located in the axial depression, but not over a deep (ESPs 6, 13, 15, Fig. 11), which show a $5-7 \mathrm{~km}$ thick crust with a seismic velocity of $5.7-6.2 \mathrm{~km} / \mathrm{s}$. The crustal structure associated with Conrad Deep appears to reflect the presence of the intrusion deduced from the magnetic anomalies (Cochran et al., 1986) while the other ESPs show a thin crust with velocities normally associated with granitic continental crust.

Fig. 10. Total intensity magnetic anomalies in the northern Red Sea contoured at 50 gamma intervals. Fine dots indicate location of data. Data presented by Pautot et al. (1986) was also incorporated in the regions around Shaban Deep and the unnamed deep. Opposing sets of brackets indicate location of transfer zones. 
The heat flow values observed in the northern Red Sea (Fig. 5) are very similar to the theoretically expected values for a mid-ocean ridge spreading at a total rate of $1 \mathrm{~cm} / \mathrm{yr}$ (Parker and Oldenburg, 1973; Parsons and Sclater, 1977). However, Buck et al. (1988) demonstrated that the heat flow data are also consistent with a model of continental extension in which extension starts over a broad area and narrows with time. Figure 12 shows a very simple case from Buck et al. (1988) with parameters chosen to simulate the northern Red Sea that reproduces the observed heat flow. The extension rate is assumed to be 1 $\mathrm{cm} / \mathrm{yr}$. The region of active rifting (using a "pure shear" mechanism) is assumed to initially be 110 $\mathrm{km}$ wide and to decrease uniformly with time, so that after 14 m.y. - the time shown in the figure- it is $20 \mathrm{~km}$ wide. This model thus reproduces the total width of the rift (about $250 \mathrm{~km}$ ), the amount of extension (about $140 \mathrm{~km}$-Joffe and Garfunkcl, 1987; Steckler ct al., this vol.) and is consistent with the observation that most of the extension must have occurred in the past $12-14$ m.y. (LePichon and Gaulier, this vol.). It is also consistent with the observation that extension, although once widespread, is now concentrated in the axial depression (Martinez and Cochran. 1988). The model preserves $4 \mathrm{~km}$ of the original $32 \mathrm{~km}$ thick continental crust at the axis.

\section{Seismic refraction results and the nature of the crust of the northern Red Sea}

An extensive set of two ship expanding spread profile (ESP) seismic experiments were carried out
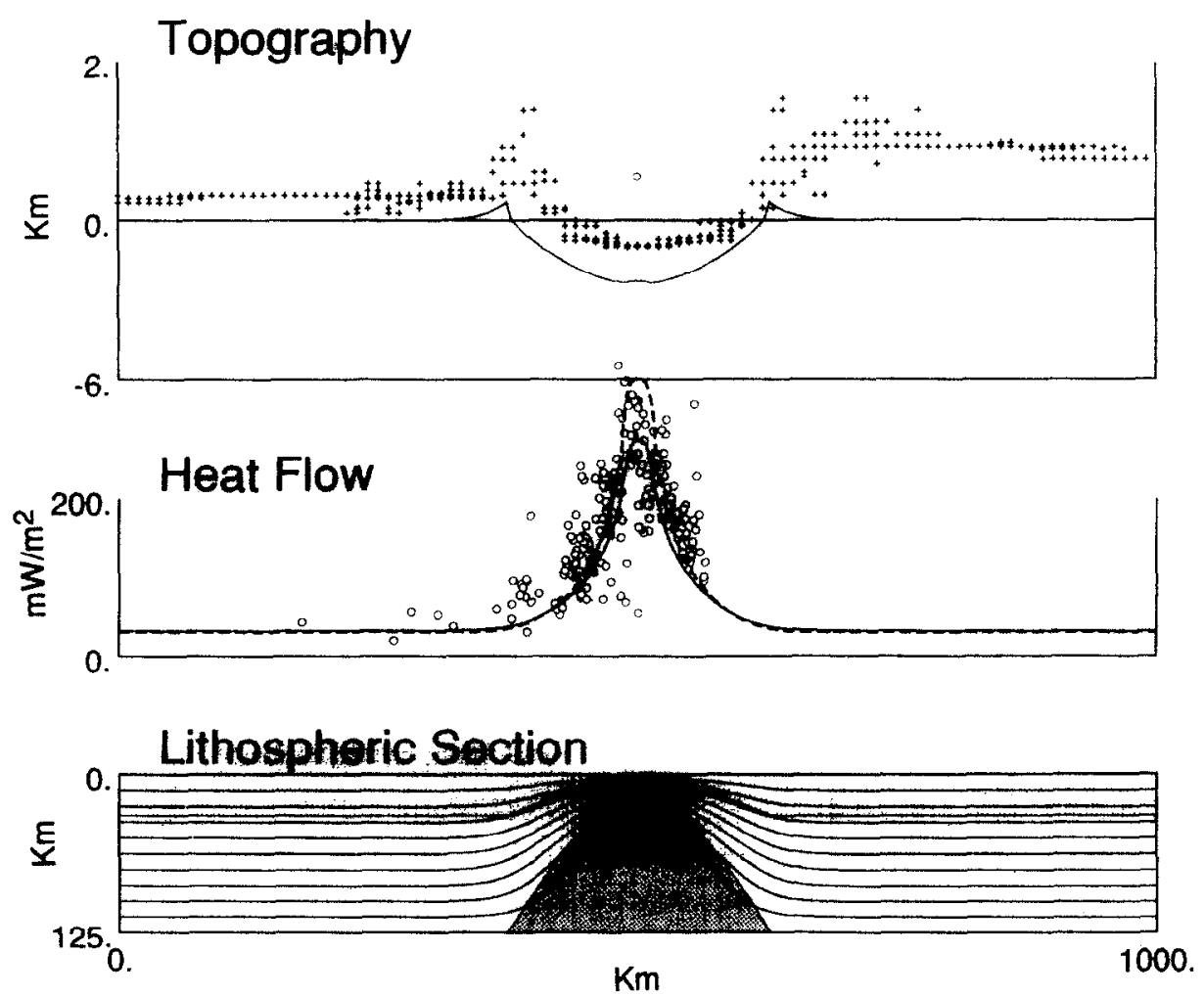

Fig. 12. Model results of rifting model at 14 m.y. after start of rifting compared with observed marine (from Conrad 1984 cruise; see Fig. 5) and terrestrial (from Morgan et al., 1985) heat flow data. Modeling techniques are discussed in Buck et al. (1988) and model thermal parameters are listed there. The lower panel shows a cross section of the lithosphere with isotherms contoured at $130^{\circ} \mathrm{C}$ intervals and the geometry of the crust (light grey) and advected asthenosphere (dark grey). Dark black area shows region of partial melting. Distances are in $\mathrm{km}$ and heat flow is in $\mathrm{mW} / \mathrm{m}^{2}$. Plate separation rate is $1 \mathrm{~cm} / \mathrm{yr}$. Initial rift width was $110 \mathrm{~km}$ narrowing at a uniform rate to $20 \mathrm{~km}$ after $14 \mathrm{~m} . y$. Solid line is for case where crustal and mantle conductivity and diffusivity are identical and the dashed line shows the probably more realistic case where crustal conductivity and diffusivity are two-thirds of the mantle values. (From Buck et al., in press.) 
in the northern Red Sea in 1986 by a group of French investigators (Gaulier et al., 1986, this vol.). The ESP's can be conveniently divided into two groups, each of which forms a traverse from the Egyptian coast to the Red Sea axis with the individual profiles oriented $\mathrm{NW}-\mathrm{SE}$ along strike of the rift (Fig. 11). The northern group is centered along a line which corresponds to our Central Heat Flow profile (Figs. 4 are 5) extending from the Egyptian coast near Safaga Island at $26^{\circ} 45^{\prime} \mathrm{N}$ toward Conrad Deep. The southern group is arranged about a line which extends from just south of $26^{\circ} \mathrm{N}$ toward Shaban Deep and thus straddles the southern end of our survey area.

Interpretation of the seismic data by Gaulier et al. (this vol.) shows a very thin crust for all of the profiles. However the northern set of profiles near $27^{\circ} \mathrm{N}$ shows relatively low crustal velocities typical of continental crust, while the southern set near $26^{\circ} \mathrm{N}$ exhibits a crustal layer with a velocity of $6.45-6.7 \mathrm{~km} / \mathrm{s}$ (Gaulier et al., this vol.). The difference in crustal velocity structure between $26^{\circ} \mathrm{N}$ and $27^{\circ} \mathrm{N}$ is also observed in a University of Hamburg ocean bottom seismometer (OBS) seismic line extending south from Safaga off the Egyptian coast. This profile shows a $6.0 \mathrm{~km} / \mathrm{s}$ upper crustal layer pinching out south of $26^{\circ} 20^{\prime} \mathrm{N}$ leaving a thin $5 \mathrm{~km}$ thick crust with a velocity of $6.3-6.5 \mathrm{~km} / \mathrm{s}$ (Makris, unpublished report).

The Quseir B-1X well, drilled by Phillips Petroleum, is located between ESPs 8 and 9 of Gaulier et al. (this vol.). The well was drilled to $4214 \mathrm{~m}$ and terminates in a crystalline rock described as a metabasite containing 10\% olivine (S. Hafez, Egyptian General. Petrol. Co., pers. commun., 1987). Girdler and Southern (1987) describe the same rock as a gabbro. Thus, it is likely that the $6.7-6.8 \mathrm{~km} / \mathrm{s}$ velocities recorded in those two ESP experiments reflect the presence of a mafic, possibly gabbroic, crust in the vicinity of those profiles. It is not clear whether the region of gabbroic crust extends as far as ESP 10 located $30 \mathrm{~km}$ seaward of the well (Fig. 11) which shows a lower velocity of $6.45 \mathrm{~km} / \mathrm{s}$ at the top of a $5.5 \mathrm{~km}$ thick crustal layer, increasing to $6.7 \mathrm{~km} / \mathrm{s}$ at its base (Gaulier et al., this vol.).

A simple explanation for the high crustal velocities on ESPs 8, 9 and 10 and the difference in the crustal seismic velocities between the northern and southern groups of ESPs (Fig. 11) is that the northern profiles demonstrate a greatly thinned continental crust, such as found at the Bay of Biscay (Fig. 1), while the southern profiles demonstrate the presence of oceanic crust (Gaulier et al., this vol.). The presence of oceanic crust beneath the southern set of ESP lines would imply that there is an abrupt transition along strike of the Red Sea from an area where about $130 \mathrm{~km}$ of extension has been accommodated by cr dstal thinning to a region where that same amount of extension has been almost entirely accommodated by the generation of new oceanic crust.

Gaulier et al. (this vol.) and LePichon and Gaulier (this vol.) argue that such an abrupt boundary could be the result of a difference in the tectonics affecting the two regions prior to about 5 m.y.B.P. They suggest that while the southern area has been subjected to extension throughout the development of the Red Sea, the northern region was within a broad Levant shear zont until the end of the Miocene when the motion became concentrated on the present Gulf of Aqaba-Dead Sea transform fault. As support for this hypothesis, they point out that, within the northwestern part of the Red Sea, the linear gravity highs interpreted by Martinez and Cochran (in press) as reflecting basement fault blocks (Figs. 6 and 7) appear to trend somewhat oblique to the coastline, while they are parallel to it on the Arabian side (see Fig. 6). They argue that this is a result of the rotation of fault blocks within the shea: zone.

Geological mapping in Sinai (Bartov et al., 1980) and in Arabia (Bayer et al., this vol.) suggests that the Levant shear was a broader feature during the Miocene. If this is the case, then it is reasonable to expect that the northern Red Sea would be affected by this shear system. In particular, if the shear zone broadens toward the southwest as proposed by LePichon and Gaulier (this vol.), then fault blocks within the shear zone could be rotated (McKenzie and Jackson, 1983, 1986).

However, even if the northernmost Red Sea has been affected by a broad continental shear zone, this does not establish that the remainder of the Red Sea must be oceanic in nature. In fact, the 
same pattern of linear gravity highs and lows interpreted by Martinez and Cochran (1988) and by LePichon and Gaulier (this vol.) as reflecting sets of basement fault blocks is also found in the eastern half of the northern Red Sea within the region interpreted by Gaulier et al. (this vol.) and LePichon and Gaulier (this vol.) as oceanic. The gravity anomalies in the eastern portion of the sea are parallel to the coast and appear to be divided into roughly $60 \mathrm{~km}$ long segments in a manner similar to those on the western side (Fig. 6).

The gravity survey of Martinez and Cochran (1988) extends only as far south as $26^{\circ} \mathrm{N}$ and thus does not delineate the gravity anomalies in the region of the southern set of ESP lines presented by Gaulier et al. (this vol.). However, a generalized gravity map of the area, based on proprietary oil company data, which shows the location and trends of the gravity highs and lows has been published by Tewfik and Ayyad (1982). This map also shows a pattern of linear gravity anomalies trending parallel to the coast. Tewfik and Ayyad (1982) interpret the gravity pattern as reflecting a series of subbasins separated by structural highs, an interpretation similar to that of Martinez and Cochran (1988) for the northern region.

The structural and morphologic pattern observed near $27^{\circ} \mathrm{N}$ where a "continental" velocity structure was recorded thus extends throughout the survey area. The southeastern half of the region displays the same pattern of 20-30 km wide bathymetric terraces with gravity highs on their outer edges as does the northwestern half. The axial depression is also present throughout the northern Red Sea, has the same morphological and structural form and appears to be subject to the same type of deformation and tectonics on both sides of the hypothesized ocean-continent boundary. The northern Red Sea appears to form a unified tectonic province.

Although often taken as diagnostic, high crustal velocities by themselves do not necessarily imply the presence of oceanic crust. Whitmarsh et al. (1986) assembled 16 seismic refraction models of very thin (less than $10 \mathrm{~km}$ thick) continental crust at a number of continental margins. They found upper crustal velocities of $6.0-6.3 \mathrm{~km} / \mathrm{s}$ in most cases, but velocities of $6.6-7.3 \mathrm{~km} / \mathrm{sec}$ in about
$25 \%$ of the refraction experiments. Whitmarsh et al. (1986) also undertook a detailed study of seismic refraction lines over very thin continental crust on the margin of the Bay of Biscay and found that the thinned continental crust actually has a higher velocity at all depths than does the adjacent oceanic crust.

The presence of high-velocity (gabbroic) crust within the Red Sea rift is consistent with geologic observations on shore. The Red Sea hills in the vicinity of Quseir consist largely of a Precambrian mafic assemblage including significant areas of gabbro, metagabbro and serpentinized ultramafics (Stern, 1981; Egyptian Geological Survey and Mining Authority, 1981; Ries et al., 1983). The presence of a metabasite (or gabbro) at the base of the Quseir B-1X well (i.e. at the top of the crystalline crust) suggests that the seismic layer with velocities of $5.0-5.4 \mathrm{~km} / \mathrm{s}$ on ESPs 8-11, which Gaulier et al. (this vol.) interpret as a basaltic crustal layer, may actually represent the Lower Miocene pre-evaporite synrift sediments. This interpretation would be consistent with their interpretation of layers with similar velocities and thicknesses on the northern set of profiles (ESPs 3-6). The sediments immediately above the basement in the Quseir B-1X well are reported to be mid-Miocene evaporites. However, the well was drilled on a pronounced structural high evident from gravity anomalies (Tewfik and Ayyad, 1982). Basement rocks were reached at a depth of about $4 \mathrm{~km}$ below sealevel, $3 \mathrm{~km}$ shallower than the 6.7 $\mathrm{km} / \mathrm{s}$ layer in ESP 9 and $6 \mathrm{~km}$ shallower than the same layer in ESP 8. The well is located between the two profiles. It is unlikely that early synrift sediments would be found on the top of a block showing that amount of relief.

The difference between the crustal velocities determined for the northern and southern sets of northern Red Sea ESP experiments (Gaulier et al., this vol.) could then be related to a fundamental change in the nature of the basement observed on shore (Fig. 13). The Eastern Desert of Egypt is divided into three sections on the basis of hasement type. The North Eastern Desert basement "is composed of 70-80\% granite, granodiorite and allied plutonic rocks and is weakly deformed" (Stern et al., 1984, p. 168). Stern et al. (1984) 
suggest that this crust formed in an extensional environment and cited the Oslo Graben as a possible analog. The Central Eastern Desert, on the other hand, is dominated by rocks of oceanic affinity such as mafic metavolcanics, gabbros, ultramafic rocks and associated metasedimentary rocks. A number of investigators have suggested that the Central Eastern Desert was formed by the collapse of a small ocean basin or back arc basin during the accretion of a series of island arc terrains which now make up the South Eastern Desert (Shackleton et al., 1980; Stern, 1981; Ries et al., 1983; El Ramly et al., 1984). These rocks were later intruded in places by Pan-African aged granites. Recently Sultan et al. (1986) used Landsat thematic mapper data to conclude that serpentized ultramafic rocks in the Central Eastern Desert are more widely distributec (perhaps by a factor of 2) than had been previously recognized. The boundary between the North Eastern Desert granitic province and the Central Eastern Desert ensimatic province is located between Safaga $\left(26^{\circ} 40^{\prime} \mathrm{N}\right.$ ) and Quseir $\left(26^{\circ} 0 \Sigma^{\prime} \mathrm{N}\right.$ ) (Fig. 13). Stern et al. (1984) describe this boundary as a

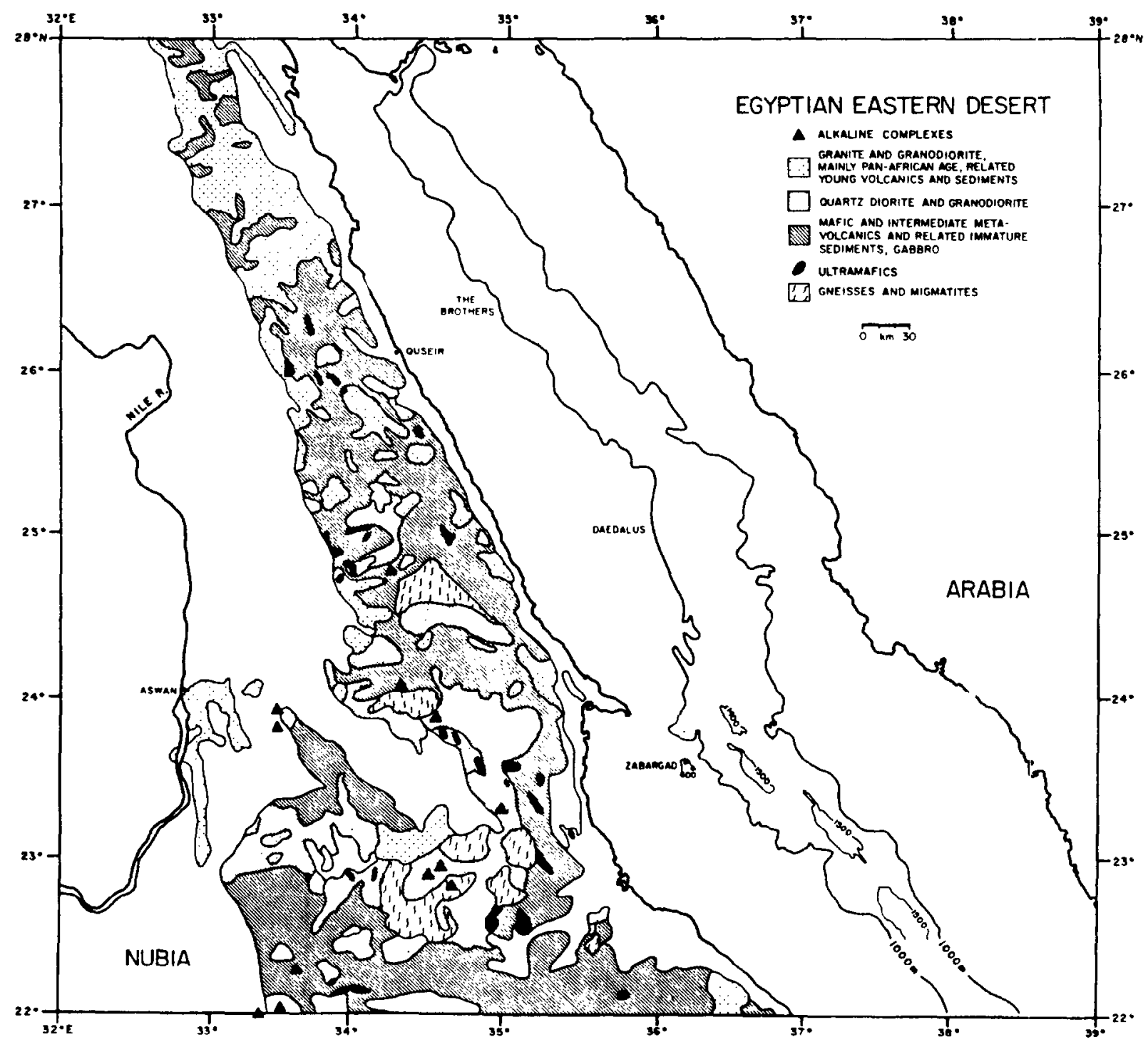

Fig. 13. Simplified geologic map of exposed basement rocks in the Eastern Desert of Egypt. Note change from primarily granitic crust to primarily mafic crust between $26^{\circ} \mathrm{N}$ and $27^{\circ} \mathrm{N}$ (from Bonatti et al., 1986). 
"major structural discontinuity" (Stern et al., 1984, p. 168). Thus, a possible explanation for the different crustal velocity structures is that the two sets of French ESP experiments sample two completely different, but both continental, basement types.

Seismic refraction studies in the Red Sea have shown a wide range of basement velocities. Tramontini and Davies (1969) report velocities of $6.4-6.6 \mathrm{~km} / \mathrm{s}$ for both the axial trough and main trough from an intensive sonobuoy study of a region approximately $80 \mathrm{~km}$ on a site centered near $22.5^{\circ} \mathrm{N}, 38^{\circ} \mathrm{E}$ within the transition zone between the northern and southern Red Sea. A two ship experiment from the same area reported by Drake and Girdler (1964) gave a basement velocity of $6.97 \mathrm{~km} / \mathrm{s}$, apparently confirming that high velocity material is present beneath the main trough in that region. However, other two ship refraction lines reported by Drake and Girdler (1964) consistently show lower "continental" velocities, generally less than $6.0 \mathrm{~km} / \mathrm{s}$, for the basement beneath the main trough. In particular, Drake and Girdler's line 175, located just outside the region of high-amplitude seafloor spreading magnetic anomalies, $10 \mathrm{~km}$ from the edge of the axial trough near $16.5^{\circ} \mathrm{N}$, gave a crustal velocity of $5.91 \mathrm{~km} / \mathrm{s}$. The depth to the refracting horizon corresponds to a smooth, block faulted reflector typical of extended continental crust on a seismic reflection profile shown by Lowell et al. (1975) and Cochran (1983) located within a few kilometers of the refraction line.

The great variation in crustal seismic velocities under the main trough of the Red Sea may be characteristic of the transition region seaward of the hinge zone of a continental margin. Talwani et al. (1979) found a similar range of seismic velocities in the "magnetic quiet zone" south of Australia. It may also, however, reflect the heterogeneous nature of the Afro-Arabian continental crust. The northeastern portion of the AfroArabian shield was assembled during the late Precambrian through the accretion of a number of subduction complexes and associated terrains onto the African shield (Gass, 1977; Schmidt et al., 1979; Engel et al., 1980) leading to the inclusion of a number of mafic and ultramafic belts within both Nubia and Arabia (Bakor et al., 1976; Frisch and Al-Shanti, 1977; Engel et al., 1980).

\section{Transition from continental to oceanic rifting; rift valley stage}

The northern Red Sea is a continental rift that has developed nearly to the point of initiation of seafloor spreading. The present stage in its development is dominated by two processes. The first is the concentration of deformation and extension, which had been widely distributed across the rift, in the axial depression and the beginning of the accommodation of this extension by intrusions. The second feature is the segmentation of the rift into roughly $60 \mathrm{~km}$ long compartments. The segmentation affects not only the marginal areas, which are divided by transfer zones into sets of fault blocks in a manner similar to other margins (Fig. 2), but also the axial depression. The location of the deeps and of the large intrusions responsible for them appear to be controlled by these same transfer zones.

Since the northern Red Sea is presently undergoing the transition from continental to oceanic rifting, it fills a gap between observations of the structure and tectonics of continental rifts, such as those of East Africa (e.g. Ebinger et al., 1984; Bosworth et al., 1986; Rosendahl, 1987) and observations of early seafloor spreading in the southern Red Sea (e.g. Bonatti, 1985; Garfunkel, et al., 1987). It thus allows development of a model for the evolution of a rift from continental to oceanic rifting and of the initiation of seafloor spreading.

Recent studies of the East African Rift indicate that the early stages of rifting are characterized by the formation of asymmetric half-graben bounded by normal faults that are curved in plan view (Ebinger et al., 1984) and have been interpreted as listric with depth (Bosworth, 1985; Bosworth et al., 1986, and Fig. 14, stage A). Within the main half-graben, the basement is broken into blocks by subsidiary normal faults (Ebinger et al., 1984; Burgess et al., in press). Along strike, other halfgrabens and associated faults are found which often have an opposite sense of dip from the adjacent ones and may also overlap adjacent boundary faults to create a complex geometry 


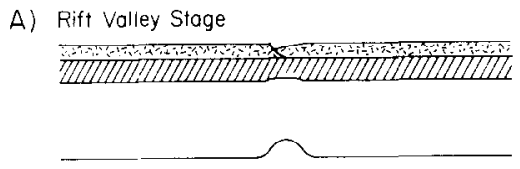

B) Gulf of Suez Stage
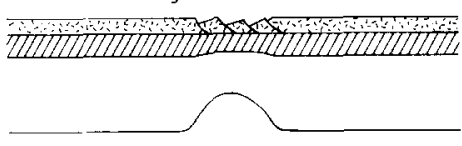

C) Intermediate Stage

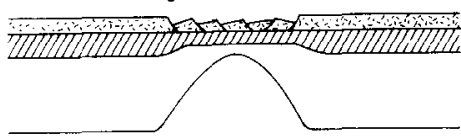

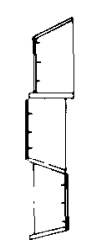

D) Northern Red Sea Stage
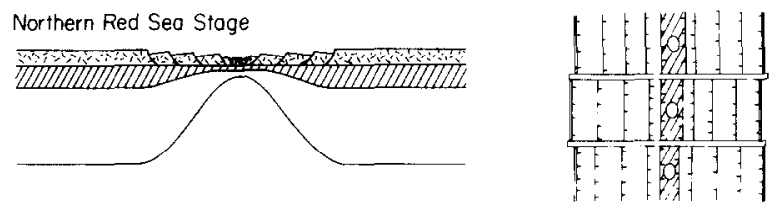

E) Central Red Seo Stage
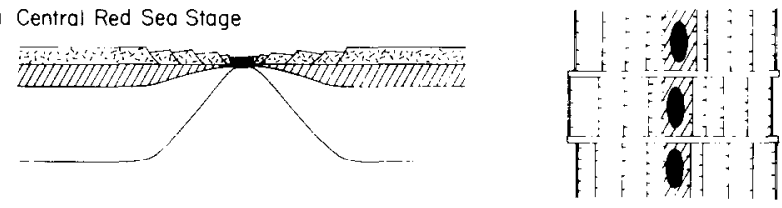
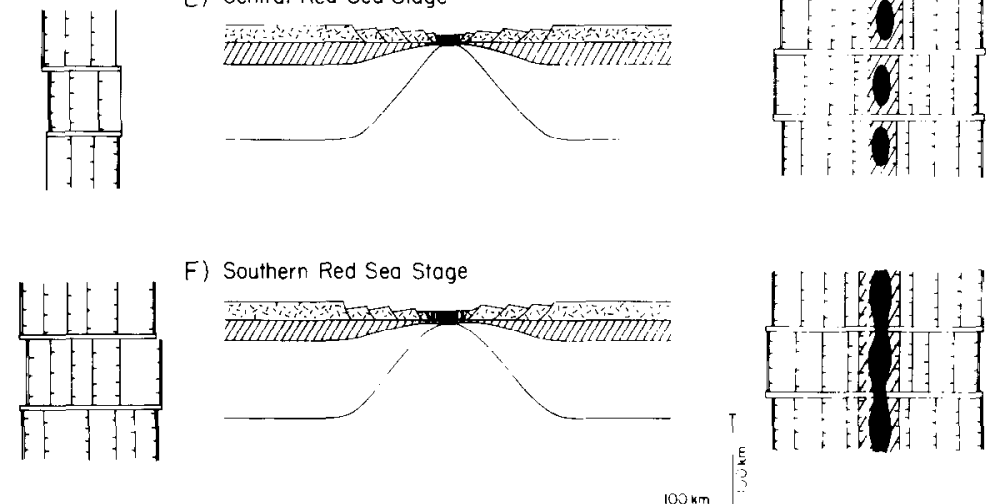

Fig. 14. Sketch showing model for the evolution of a continental rift into a continental margin and mid-ocean ridge. Details of the model are discussed in the text. Each state shows an idealized cross section (on left) and plan view (on right). In Stage D diagonally ruled area in plain view represents the axial depression and white ellipses within the axial depression are deeps. In Stagıs E and F, solid black areas represent oceanic crust.

(Burgess et al., in press). These half-grabens evolve as independent sub-basins within the main rift (Ebinger et al., 1984; Bosworth et al., 1986).

The segmentation of the rift thus begins with its inception. The length of individual segments is determined by the curvature of the master fault, which is fairly consistent throughout the East African rift. Typical spacings of $60 \mathrm{~km}$ have been reported for Lake Malawi (Ebinger et al., 1984) and $40 \mathrm{~km}$ for Lake Tanganyika (Burgess et al., in press). Transfer zones characterized by strike-slip or "scissor" motion must thus develop early in the development of a rift. Burgess et al. (in press) discuss various geometries observed in Lake Tanganyika and state that transfer zones can occur either by development of a distinct strike-slip fault or by utilization of the oblique portions of the boundary faults.

The pattern of interlocking en-echelon half grabens linked by transfer zones has been observed at a number of major rift systems. For example, Chapin (1979) notes that the Rio Grande Rift formed a series of NE and WNW trending lineaments and that "basins forming on opposite sides of lineaments developed opposing; symmetries, hinged on the west versus hinged on the east" (Chapin, 1979, p. 1). Chapin (1979) also states that the regions connecting the ends of the staggered basins were subjected to a scissors like torque in the near surface and transverse shear at depth with this strain relieved mainly by a complex intermeshing of normal faults of opposing sense. Data presented in detailed studies of portions of the Rio Grande Rift suggests that individual sub-basins may have lengths of $40-60 \mathrm{~km}$ in New Mexico (Kelley, 1979; Manley, 1979) and perhaps as much as $75 \mathrm{~km}$ in Colorado (Tweto, 1979). The Baikal rift system also is made up of a series of sub-basins, often with an asymmetric cross section (Logatchev and Florensov, 1978; Zorin and Rogazhina, 1978). The boundary faults are described as bcing made up of en-echelon segments usually $40-60 \mathrm{~km}$ in length (Sherman, 1978).

The pattern of asymmetric half grabens separated by transfer zones which characterizes the East African Rift is also observed in the Gulf of Suez (Fig. 14, Stage B). Moustafa (1976) divided 
the Gulf of Suez into three major tectonic provinces separated by NE-SW trending "hinge zones". Within each province, the rift is characterized by a series of rotated fault blocks with a constant sense of dip, giving the sub-basin a highly asymmetric cross-sectional shape (Moustafa, 1976; Steckler, 1985).

Steckler et al. (1986) has suggested that data on cross faults presented by Sultan and Schütz (1984) combined with offset of fault block structures observed on land (Garfunkel and Bartov, 1977; Chenet et al., 1984) imply the existence of an additional transfer zone just north of Gebel Abu Durba and Gebel Nazzazat. This zone was not reported by Moustafa (1976) because the dip direction of the faults does not change across it. Data presented by Sultan and Schütz (1984) also suggests that the northernmost transfer zone (Moustafa's Galala-Genima hinge zone) should be located about $15 \mathrm{~km}$ north of where Moustafa (1976) placed it. The Gulf of Suez thus appears to consist of four sub-basins each about $60 \mathrm{~km}$ in length. Each sub-basin has an asymmetric cross section and consists of a series of rotated fault blocks bounded by normal faults which have a consistent dip direction within each sub-basin.

The two northern transfer zones trend oblique to the fault blocks as is the case for the East African Rift (Bosworth et al., 1986; Burgess et al., in press) while the southern transfer zone is almost perpendicular to the strike of the normal faults as is observed in the northern Red Sea (Martinez and Cochran, 1988). The oblique nature of the transfer zones in the early stages of rifting appears to result from the utilization of the oblique sections of the curved or "spoon shaped" faults that result from listric faulting (Gibbs, 1984; Bosworth et al., 1986). Simple geometry requires, however, that as the amount of extension increases, the transfer zones must become more orthogonal (although they may be made up of a set of en echelon oblique features).

It has recently become recognized that extension in continental regions commonly occurs at upper crustal levels by the development of a series of rotated fault blocks with the normal faults bounding the blocks truncated against or soling into a main low angle detachment fault (Wernicke,
1981; Hamilton, 1982; Anderson et al., 1983). It has also been suggested that these detachments continue completely through the crust and the entire lithosphere, either as a single detachment (Wernicke, 1981, 1985) or as a series of ramps (Lister et al., 1986). This asymmetric "simpleshear" model of lithospheric extension has been applied to the Red Sea in a qualitative manner by Wernicke (1985) to explain an asymmetry in elevation and in the distribution of volcanic activity across the Red Sea.

Bosworth (1985) and Bosworth et al., (1986) have suggested that the observed pattern of a sequence of half grabens of alternating asymmetry results from the simultaneous development of two opposing low angle detachments separated by $30-50 \mathrm{~km}$. Bosworth (1985) hypothesizes that one of the detachments locally gains an advantage and is utilized for extension resulting in the locking of the other. In the next sub-basin, the other detachment may gain the initial advantage, forcing a reversal in the asymmetry of the extension. Although not explicitly developed, such a scheme is also implied by a model for the development of continental margins proposed by Lister et al. (1986).

If the detachments cut the entire lithosphere, as proposed by Bosworth et al. (1986) and Lister et al. (1986), then this model implies that rather than separating along a single, shallow-dipping detachment, long sloping lithospheric prisms $60 \mathrm{~km}$ wide and hundreds of kilometers long are pulled past each other, much like the pulling apart of two hands with interlocking fingers. Such a mechanism may be possible, but it represents a fundamental change in the simple detachment model of Wernicke (1981).

The periodic reversal of dip on the boundary faults may, however, also be interpreted as evidence that the detachment surfaces do not penetrate the entire lithosphere, but are actually surficial and confined to the upper half of the crust. The detachment surfaces could then pass into a sub-horizontal decoupling zone between brittle extension in the upper plate and penetrative ductile extension in the lower plate (Miller et al., 1983) or into a network of lenses (Hamilton, 1982) or anastomosing shear zones (Kligfield et 
al., 1984) with extension through ductile pure shear at deeper levels. These types of models may be supported by the observation that while metamorphic core complexes exposed in detachments originate at depths greater than $10 \mathrm{~km}$ (Hamilton, 1982), they do not expose mantle rocks. Allmendinger et al. (1987) also note that the reflection fabric of the crust and the nature of the Moho on the COCORP $40^{\circ} \mathrm{N}$ seismic reflection transect of the U.S. Cordillera is consistent with the lenses model of Hamilton (1982). The form of the extension in the lower crust and mantle is deliberately left vague in Fig. 14, but is shown as being symmetric under the rift consistent with a model such as that presented by Hamilton (1982) or Miller et al. (1983).

The Gulf of Suez has experienced about $25 \mathrm{~km}$ of extension in its central portion (Steckler, 1985), and perhaps $35 \mathrm{~km}$ at its southern end. This is considerably more extension than has occurred in the East African Rift. Estimates of the amount of extension for the portion of the Gregory Rift discussed by Bosworth et al. (1986) range from 8 to $15 \mathrm{~km}$ (Baker and Wohlenberg, 1971; Fairhead, 1976; Swain, 1976). Arguments presented by King (1978) suggest about 6-12 km of extension for the rifts forming Lakes Tanganyika and Malawi and discussed by Burgess et al. (in press) and Ebinger et al., (1984). Thus, up until at least the amount of opening represented by the Gulf of Suez, the pattern of block faulting and rotation within an asymmetric half-graben established at the earliest stages of rifting is capable of producing the necessary extension.

\section{Transition from continental to oceanic rifting, Red Sea stage}

The Gulf of Suez appears to have formed as part of the Red Sea rift prior to the initiation of transform motion on the Dead Sea transform in the Middle Miocene (Heybroek, 1965; Steckler and Ten Brink, 1986). Thus, the geometry of rifting in the Gulf of Suez (Fig. 14, stage B) probably represents that of the Red Sea at that stage of its development.

The amount of opening in the northern Red Sea can be estimated at about $140 \mathrm{~km}$ (Le Pichon and Francheteau, 1978; Cochran, 1981, 1983), a factor of four to five greater than that in the Gulf of Suez. At some point during that opening, a fundamental change occurred in the geometry of the rift. It lost the asymmetric cross section characteristic of continental rifts and developed a more symmetric nature with rotated blocks stepping down toward the center (Fig. 14, stage: C). This probably occurred through the develcpment of antithetic faults in what had been the hanging wall. However, there is no obvious example of a rift preserved in or presently going th*ough this stage in its development.

Data presented here and in Martinez and Cochran (1988) implies that extension in the northern Red Sea has recently become concentrated in a well defined axial depression. Subsurface deformation on seismic reflection records (Fig. 8) and thinned crust of the marginal areas of the rift (Gaulier et al., this vol.) indicates that the extension had been much more widely cistributed. The establishment of an axial depression marks the beginning of the delineation of a well defined, narrow plate boundary.

The focussing of extension within the axial depression has been accompanied in the northern Red Sea by the beginning of the emplacement of large intrusions within the rift. These intrusions are not randomly distributed but magnetics data (Fig. 10) imply that they occur at two distinct locations (Martinez and Cochran, in press). One is in the marginal areas at the intersection of the transfer zones with the faults bounding the rotated fault blocks. The other location is within the axial depression halfway between the transfer zones where they form "deeps" (Fig. 14, stage D). With the exception of the northernmost segment, which is complicated by the intersection with the Aqaba transform, a deep associated with large dipolar magnetic anomalies, is located half way between each set of transfer zones within the survey area (Figs. 4 and 10).

Regularly spaced deeps about $60 \mathrm{krn}$ apart are also present farther south in the Central Red Sea. However, these transition zone deeps, located between $21^{\circ} \mathrm{N}$ and $23^{\circ} 20^{\prime} \mathrm{N}$ are larger and deeper than the northern Red Sea deeps. Nereus Deep, the furtherst north of the transition zone deeps, is 
about $10 \mathrm{~km}$ wide, $25 \mathrm{~km}$ long and reaches depths exceeding 2300m (Bäcker et al., 1975; Pautot, 1983). The deeps farther south become gradually longer and wider. They are associated with steep, faulted walls, a rough bottom and large magnetic anomalies which appear lineated along the length of the deeps (Cochran, 1983; Pautot, 1983; Bonatti et al., 1984). The floor of the deeps appears to be made up of young basalts with affinities to those found at mid-ocean ridges (Bonatti et al., 1984; Bonatti, 1985). A volcanic ridge runs up the center of Nereus Deep (Bonatti et al., 1984) which a detailed deep-tow survey (Bicknell et al., 1986) found to be very similar to a mid-ocean ridge "neovolcanic zone" flanked by regions of fissuring and faulting. The transition zone deeps between $21^{\circ} \mathrm{N}$ and $23^{\circ} 20^{\prime} \mathrm{N}$ thus appear to be short segments of well developed mid-ocean ridge-type spreading centers.

Seafloor spreading anomaly $2(1.7$ m.y.B.P) is not present over the Atlantis II Deep (the southernmost deep) (Searle and Ross, 1975) and it does not appear that the Jaramillo event (0.92 m.y.B.P.) is present in published profiles over the northern deeps. Thus, organized seafloor spreading has begun very recently at the transition zone deeps.

They do not, however, join to form a continuous mid-ocean ridge, but are separated by "intertrough zones" which are shallower (1100-1500 m) with gentler sloping sides and no significant magnetic anomalies (Searle and Ross, 1975; Cochran, 1983). The intertrough zones are underlain by thick sediments and Reflector $S$ can be traced across the axis of the Red Sea within them (Searle and Ross, 1975). The sediments within the intertrough zone are highly faulted and deformed (P. Guennoc, pers. commun., 1986) and these regions have an appearance similar to the axial depression of the northern Red Sea.

It thus appears that the northern Red Sea deeps, which are the result of isolated intrusions, serve as nucleation points which with further repeated intrusions develop into small cells of a mid-ocean ridge type spreading center such as observed in the Central Red Sea (Fig. 14, stage E).

Bonatti (1985) has argued that the continuous spreading center observed in the southern Red Sea has resulted from the growth and coalescence of these isolated cells (Fig. 14, stage F). This suggestion is supported by observations of the morphotectonic and magnetic fabric of the southern Red Sea. GLORIA side scan sonar data show that many straight sub-parallel faults are developed in the axial trough (Garfunkel et al., 1987), resembling the tectonic fabric commonly observed along slow spreading mid-ocean ridges (Searle and Laughton, 1981). The spreading center is made up of straight segments which are stepped laterally 3-10 km across non-transform "relay zones" spaced about $50 \mathrm{~km}$ along the ridge (Garfunkel et al., 1987). As the relay zones are approached the magnetic anomalies become irregular and do not extend as far from the axis (Roeser, 1975: Bonatti, 1985).

Bonatti (1985) has suggested that the transition zone deeps result from regularly spaced asthenospheric diapirs possibly caused by a Raleigh-Taylor instability. This type of instability occurs when a denser fluid overlies a lighter fluid and results in the formation of regularly spaced instabilities and upwelling diapirs, the spacing of which depends upon the thickness of the two layers and their viscosity. Such a mechanism has been suggested to control the supply of magma and the distribution of eruptive centers at mature mid-ocean ridges (Whitehead et al., 1984; Crane, 1985). It has been argued that the most likely source for the generation of the harmonic instabilities beneath mid-ocean ridges is the base of the 15-20\% partial melt zone (Whitehead et al., 1984; Crane, 1985) which is predicted to be at a depth of $40-60 \mathrm{~km}$ under mid-ocean ridges (Forsyth, 1977; Crane, 1985).

However, the location and spacing of the nucleation points in the Red Sea appears to be controlled by the segmentation of the rift into sub-basins which form at the earliest stages of rifting (Fig. 14A). Since the detachments, and thus also the transfer zones that bound them, appear to be crustal (and probably mid and upper crustal) features, it is unlikely that they could interact with deeper instabilities to control the location of the deeps. The preferred sites for intrusions and for the nucleation points for seafloor spreading appears rather to be controlled by shallow crustal structure and processes.

The transfer zones are complexly faulted re- 
gions, which where they are observed in East Africa (Ebinger et al., 1984; Bosworth et al., 1986) or the Gulf of Suez (Moustafa, 1976), have widths of $5-10 \mathrm{~km}$. These zones appear to be composed of pervasive cross faulting which makes them less cohesive and less rigid than the block faulted regions between them. The northern Red Sea stage in the development of a rift is characterized by a narrowing and focusing of the zone of active extension into the axial depression. It can be speculated that the focusing might be more efficient and faster in the block faulted regions because there are fewer major faults that can be utilized for taking up the upper crustal extension. During the final stages, this could result in a zone of extension which widens out at the transfer zones and narrows between them. This speculation is supported by the observation that depths in the axial depression increase away from the transfer zones toward the deeps (Fig. 4). Narrowing of the zone of extension away from the transfer zones would make the center of the individual block faulted provinces the preferred location for rupturing of the crust and emplacement of large intrusions.

\section{Summary and conclusions}

The northern Red Sea can be divided into two distinct morphologic and tectonic provinces. The "marginal areas" consist of a series of bathymetric terraces that step down from both coasts toward the center of the sea. Geophysical evidence implies that these terraces are the subdued expression of a series of rotated fault blocks $20-30 \mathrm{~km}$ across. Sets of fault blocks are truncated at roughly $60 \mathrm{~km}$ intervals by transverse, transfer zones which serve to absorb differential motion between the sets of fault blocks.

The "axial depression" is a continuous region near the center of the Red Sea which forms the axis of deep water. The maximum values of a heat flow high extending completely across the Red Sea are found within the axial depression. The axial depression is underlain by the same sedimentary sequence as is found in the marginal areas including the Miocene evaporites. However, the sediments in the axial depression are much more deformed and faulted than are those in the marginal areas, and present faulting and deformation appears to be concentrated in the axial depression. Small deeps which appear to result from isolated intrusions are located at periodic intervals within the axial depression, midway between transfer zones.

The geological and geophysical data imply that the opening between Africa and Arabia is becoming concentrated within the axial depression. Although we have no evidence on the nature of extension in the lower crust and mantle, the combination of magnetics and heat flow diata can be used to argue that at least the upper $f \in w$ kilometers of the crust consist of continental material. Thus, although the formation of the axial depression as an axis of extension and the emplacement of large igneous bodies in the "deeps" are major steps in the establishment of a spreading center, seafloor spreading has not yet begun in the northern Red Sea.

Seismic refraction data in the northern Red Sea show a number of different crustal velocity structures, including measurements that could be interpreted to imply that a portion of the northern Red Sea is underlain by oceanic type crust. This interpretation appears to be in conflict with other geophysical data that shows the northern Red Sea to be a unified tectonic province demonstrating the same structures and tectonics in the region of "oceanic" velocities as in the region of clearly "continental" velocities. It is possible that the different seismic velocities observed under the Red Sea reflect fundamental differences in the nature of the basement rocks observed on land in the Red Sea hills of eastern Egypt.

The northern Red Sea occupies a critical position in the transition from continental to oceanic extension in a rift. Observations of the structure and tectonics of the northern Red Sea allow a qualitative model for that transition to be developed. The first stage involves the formation of a series of linked asymmetric half graben. The segmentation of the rift starts at this early stage with the development of accommodation or transfer zones linking the half grahen. The polarity of half graben can change across transfer zones suggesting that, if the half grabens form above a detach- 
ment surface, the detachments are likely to be surficial, upper crustal features and do not penetrate deep into the mantle.

The Gulf of Suez, which was part of the Red Sea until cut off by development of the Aqaba transform, demonstrates this linked half-graben geometry. This suggests both that at least $35 \mathrm{~km}$ of extension can be accommodated in this manner and that the Red Sea also had this tectonic style early in its development.

A second stage in the development of the rift can be observed by moving from north to south in the Red Sea. At some point between the $35 \mathrm{~km}$ of opening in the southern Gulf of Suez and the 140 $\mathrm{km}$ of opening in the northern Red Sea, the rift develops a more symmetric profile. This may occur by the breakup of the "hanging wall" by antithetic faulting. Tectonic activity appears to have been initially widespread through the rift, but has become concentrated in a well defined axial depression characterized by high heat flow and intense deformation of the sediments. Intrusion of basaltic magma into the upper crust began at this stage and resulted in the formation of small "deeps" within the axial depression evenly spaced halfway between the transfer zones. These deeps serve as nucleation points, which with further intrusion develop into small cells of a mid-ocean ridge type spreading center and eventually grow and coalesce to form a continuous spreading center.

\section{Acknowledgements}

We would like to thank the governments of the Arab Republic of Egypt and of the Kingdom of Saudi Arabia for granting clearance for the R.V. "Robert D. Conrad" cruise which served as the basis of this study. The manuscript was reviewed by P. Guennoc, M.S. Steckler, X. LePichon, W.R. Buck and J.K. Weissel. The work was supported by the U.S. National Science Foundation grant OCE 83-09983. Lamont-Doherty Geological Observatory contribution number 4316 .

\section{References}

Allmendinger, R.W., Hauge, T.A., Hauser, E.C., Potter, C.J., Klemperer, S.L., Nelson, K.D., Knuepfer, P. and Oliver, J., 1978. Overview of the COCORP $40^{\circ} \mathrm{N}$ transect, western
United States: the fabric of an orogenic belt. Geol. Soc. Am. Bull., 98: 308-319.

Anderson, R.E., Zoback, M.L. and Thompson, G.A., 1983. Implications of selected subsurface data on the structural form and evolution of some basins in the northern basin and range province, Nevada and Utah. Geol. Soc. Am. Bull., 94: 1055-1072.

Avedik, F., Camus, A.L., Ginsburg, A., Montadert, L., Roberts D.G. and Whitmarsh, R.B., 1982. A seismic refraction and reflexion study of the continent-ocean transition beneath the north Biscay margin. In:. P. Kent, M.H.P. Bott, D.P. McKenzie, C.A. Williams (Editors), The Evolution of Sedimentary Basins. The Royal Society, London, pp. 27-44.

Bäcker H., Lange, K. and Richter H., 1975. Morphology of the Red Sea central graben between Subair Islands and Abul Kizaan. Geol. Jahrb., D13: 79-123.

Baker, B.H. and Wohlenberg, J., 1971. Structure and evolution of the Kenya rift valley. Nature, 229: 538-542.

Bakor, A.R., Gass, I.G. and Neary, C.R., 1976. Jabal al Wask, northwest Saudi Arabia: an Eocambrian back-arc ophiolite. Earth Planet. Sci., Lett., 30: 1-9.

Barakat, H. and Miller, P.M., 1984. Geology and petroleum exploration, Safaga Concession, Northern Red Sea, Egypt. Egyptian General Petroleum Corp., 7th Explor. Sem., 26 pp.

Bartov, Y., Steinitz, G., Eyal, M. and Eyal, Y., 1980. Sinistral movement along the Gulf of Ayaba-its age and relation to opening of the Red Sea. Nature, 285: 220-221.

Bayer, H.-J., Hötzl, H., Jado, A.R., Roscher, B. and Voggenreiter W., 1988. Sedimentary and structural evolution of the northwest Arabian Red Sea margin. Tectonophysics, 153 (this vol.): 137-151.

Berthelot, F., 1986. Etude thermique du Golfe de Suez dans son contexte géodynamique. These $3 e$ cycle, Univ. Pierre et Marie Curie, Paris, 194 pp.

Bicknell, J.D., Macdonald, K.C., Miller, S.P., Lonsdale, P.F., and Becker, K., 1986. Tectonics of the Nereus Deep, Red Sea: a deep tow investigation of a site of initial rifting. Mar. Geophys. Res., 8: 131-148.

Boeuf, M.G. and Doust, H., 1975. Structure and development of the southern margin of Australia. Aust. Pet. Explor. Assoc. J., 15: 33-43.

Bonatti, E., 1985. Punctiform initiation of seafloor spreading in the Red Sea during transition from a continental to an oceanic rift. Nature, 316: 33-37.

Bonatti, E., Colantoni, P., Della Vedova, B. and Taviani, M., 1984. Geology of the Red Sea transitional zone $\left(22^{\circ} \mathrm{N}-25^{\circ} \mathrm{N}\right)$. Oceanol. Acta, 7: 385-398.

Bosworth, W., 1985. Geometry of propagating continental rifts. Nature, 316: 625-627.

Bosworth, W., Lambiase, J. and Keisler, R., 1986. A new look at Gregory's rift: the structural style of continental rifting. Eos, Trans. Am. Geophys. Union, 67: 577-583.

Buck, W.R., Martinez, F., Steckler, M.S. and Cochran, J.R., 1988. Thermal consequences of lithospheric extension: pure and simple. Tectonics, 7: 213-234.

Burgess, C.F., Rosendahl, B.R., Sander, S., Burgess, C.A. 
Lambiase, J., Derksen, S. and Meader, N., in press. The structural and stratigraphic evolution of Lake Tanganyika: a case study of continental rifting. J. Geol. Soc. London.

Chapin, C.E., 1979. Evolution of the Rio Grande rift-a summary. In: R.E. Riecker (Editor), Rio Grande Rift: Tectonics and Magmatism. Am. Geophysical Union, Washington, D.C., pp. 1-5.

Chenet, P.-Y., Letouzey, J. and Zaghloul, E.S., 1984. Some observations on the rift tectonics in the eastern part of the Suez rift. Egyptian General Petroleum Corp., 7th Explor. Sem., 32 pp.

Cochran, J.R., 1981. The Gulf of Aden: structure and evolution of a young ocean basin and continental margin. J. Geophys. Res.. 86: 263-288.

Cochran. J.R., 1982. The magnetic quiet zone in the eastern Gulf of Aden: implications for the early development of the continental margin. Geophys. J.R. Astron. Soc., 68: 171-201.

Cochran, J.R., 1983. A model for the development of the Red Sea. Am. Assoc. Pet. Geol. Bull., 67: 41-69.

Cochran, J.R., Martinez, F., Steckler, M.S. and Hobart, M.A., 1986. Conrad Deep: a new northern Red Sea deep. Origin and implications for continental rifting. Earth Planet. Sci. Lett., 78: 18-32.

Crane, K., 1985. The spacing of rift axis highs: dependence upon diapiric processes in the underlying asthenosphere. Earth Planet. Sci. Lett., 72: 405-414.

De Charpal, O., Guennoc, P. Montadert, L. and Roberts. D.G., 1978. Rifting, crustal attenuation and subsidence in the Bay of Biscay. Nature, 275: 706-711.

Drake. C.L. and Girdler, R.W., 1964. A geophysical study of the Red Sea. Geophys. J.R. Astron. Soc., 8: 473-495.

Ebinger, C.J., Crow, M.J., Rosendahl, B.R., Livingstone, D.A. and LeFournier, J., 1984. Structural evolution of lake Malawi, Africa. Nature, 308: 627-629.

Egyptian Geological Survey and Mining Authority, 1981. Geological map of Egypt. Egyptian Geological Survey, Cairo.

El-Ramly, M.F., Kröner, A., Greiling, R. and Rashwan, A.A.A., 1984. On the tectonic evolution of the Wadi Hafafit area environs, Eastern Desert of Egypt. King Abdulaziz Univ., Fac. Earth Sci. Bull., 6: 113-126.

Engel, A.E.J., Dixon, T.H. and Stern, R.J., 1980. Late Precambrian evolution of Afro-Arabian crust from ocean arc to craton. Geol. Soc. Am. Bull, 91: 699-706.

Fairhead, J.D., 1976. The structure of the lithosphere beneath the eastern rift, East Africa, deduced from gravity studies. Tectonophysics, 30: 269-298.

Forsyth, D.W., 1977. The evolution of the upper mantle beneath mid-ocean ridges. Tectonophysics. 38: 89-119.

Frisch, W. and Al-Shanti, A., 1977. Ophiolite belts and the collision of island arcs in the Arabian Shield. Tectonophysics, 43: 293-306.

Garfunkel, Z. and Bartov, Y., 1977. The tectonics of the Suez rift. Geol. Surv, Israel Bull,. 71: 44 pp.

Garfunkel, Z., Ginzburg, A. and Searle, R.C., 1987. Fault pattern and mechanism of crustal separation along the axis of the Red Sea from side scan sonar (GLORIA) data. Ann. Geophys., 5B: $187-200$.

Gass, I., 1977. The evolution of the Pan-African crystalline basement in NE Africa and Arabia. J. Geol. Soc. London. 134: 129-138.

Gaulier, J.-M., LePichon, X., Lyberis, N., Avedik, F. and Moretti, I., 1986. New refraction data on the northern Red Sea-Gulf of Suez area (abstr.). Eos, Trans. Am. Geophys. Union, 67: 1208.

Gaulier, J.-M., LePichon, X., Lyberis, N., Avedik, F., Geli, L. Morett, I., Deschamps, A. and Hafez, S., 1988. Seismic study of the crust of the northern Ked Sea and Gulf of Suez, Tectonophysics, 153 (this vol.): $55-88$.

Gibbs, A.D., 1984. Structural evolution of extensional basin margins. J. Geol. Soc, London, 141: 609-620.

Ginzburg, A., Whitmarsh, R.B., Roberts, D.G., Montadert, L.. Camus, A. and Avedik, F., 1985. The deep seisrnic structure of the northern continental margin of the Bay of Biscay. Ann. Geophys., 3: 499-510.

Girdler, R.W. and Southren, T.C., 1987. Structure and evolution of the northern Red Sea. Nature, 330: 71t,-721.

Guennoc, P., Pautot, G. and Coutelle, A. 1988. Surficial structures of the Northern Red Sea axial valley from $23^{\circ} \mathrm{N}$ to $28^{\circ} \mathrm{N}$ : time and space evolution of neooceanic structures. Tectonophysics, 153 (this vol.): 1-23.

Hamilton, W.B., 1982. Structural evolution of the Big Maria Mountains, northeastern Riverside County, southeastern California. In: E.G. Frost and D.L. Martin (Editors). Mesozoic-Cenozoic Tectonic Evolution of the Colorado River Region, California, Arizona and Nevada. Cordilleran Press, San Diego, Calif., pp. 1-27.

Heybroek, F., 1965. The Red Sea Miocene evapor te basin. In: Salt Basins Around Africa. Institute of Petroleum, London pp. $17-40$.

Jansa, L.F. and Wade, J.A., 1975. Geology of the continental margin off Nova Scotia and Newfoundland. In: C.J. Yorath, E.R. Parker and D.J. Glass (Editors), Offshore: Geology of Eastern Canada. Geol. Surv. Can., Pap. 74-30, 2: 51-105.

Joffe, S. and Garfunkel, Z., 1987. Plate kinematics of the circum Red Sea-a re-evaluation. Tectonophysics, 141 : $5-23$.

Keen, C.E. and Barrett, D.L. 1981. Thinned and subsided crust on the rifted margin of eastern Canada: crustal structure, thermal evolution and subsidence history. Grophys. J. R. Astron. Soc., 65: 443-465.

Kelley, V.C., 1979. Tectonics, Middle Rio Grande rift, New Mexico. R.E. Riecker (Editor), Rio Grande Rift: Tectonics and Magmatism. American Geophysical Union, Washington, D.C. pp. $57-70$.

King, B.C., 1978. Structural and volcanic evolution of the Gregory Rift. In: W.W. Bishop (Editor), Geological Background to Fossil Man. Spec. Publ., Geol. Soc. London, 6: 347-350.

Kligfield, R., Crespi, J., Naruk, J. and Davis, G.H., 1984. Displacement and strain patterns of extensional orogens. Tectonics, 3: 577-609. 
LePichon, X. and Francheteau, J., 1978. A plate tectonic analysis of the Red Sea-Gulf of Aden area. Tectonophysics, 46: 369-406.

LePichon, X. and Gaulier, J.-M., 1988. The rotation of Arabia and the Levant Fault System. Tectonophysics, 153 (this vol.): 271-294.

LePichon, X. and Sibuet, J.-C., 1981. Passive margins: a model of formation. J. Geophys. Res., 86: 3708-3720.

Lister, G.S., Etheridge, M.A. and Symonds, P.A., 1986. Detachment faulting and the evolution of passive continental margins. Geology, 14: 246-250.

Logatchev, N.A. and Florensov, N.A., 1978. The Baikal system of rift valleys. Tectonophysics, 45: 1-13.

Lowell, J.D., Genik, G.J., Nelson, T.H. and Tucker, P.M., 1975. Petroleum and plate tectonics of the southern Red Sea. In: A.G. Fisher and S. Judson (Editors), Petroleum and Global Tectonics. Princeton University Press, Princeton, N.J., pp. 129-156.

Manley, K., 1979. Stratigraphy and structure of the Espanola Basin, Rio Grande Rift, New Mexico. In: R.E. Riecker (Editor), Rio Grande Rift: Tectonics and Magmatism. American Geophysical Union, Washington, D.C., pp. $71-86$.

Martinez, F. and Cochran, J.R., 1988. Structure and tectonics of the northern Red Sea: catching a continental margin between rifting and drifting. Tectonophysics 150: 1-32.

McKenzie, D. and Jackson, J.A., 1983. The relationship between strain rates, crustal thickening, paleomagnetism, finite strain and fault movements within a deforming zone. Earth Planet. Sci. Lett., 65: 182-202.

McKenzie, D. and Jackson, J.A., 1986. A block model of distributed deformation by faulting. J. Geol. Soc., London, 143: 349-353.

Miller, E.L., Gans, P.B., and Garing, J., 1983. The Snake Range decollement: an exumed mid-Tertiary ductile brittle transition. Tectonics, 2: 239-263.

Miller, P.M. and Barakat, H., 1988. Geology of the Safaga Concession, Northern Red Sea, Egypt. Tectonphysics, 153 (this vol.): 123-136.

Miller, S.P., Macdonald, K.C. and Lonsdale, P., 1985. Near bottom magnetic profile across the Red Sea. Mar. Geophys. Res., 7: 401-418.

Montadert, L., de Charpal, O., Roberts, D.G., Guennoc, P. and Sibuet, J., 1979. Northeast Atlantic passive continental margins: rifting and subsidence processes. In: M. Talwani, W. Hey and W.B.F. Ryan (Editors), Deep Drilling Results in the Atlantic Ocean: Continental Margins and Paleoenvironment. Am. Geophysical Union, Washington, D.C., pp. 154-186.

Moustafa, A.M., 1976. Block faulting in the Gulf of Suez. Egyptian General Petroleum, Corp., 7th Explor. Sem., 19 pp.

Parker, R.L. and Oldenburg, D.W., 1973. Thermal model of ocean ridges. Nature (London), Phys. Sci., 242: 137-139.

Parsons, B. and Sclater, J.G., 1977. An analysis of ocean floor bathymetry and heat flow with age. J. Geophys. Res., 82: 803-827.
Pautot, G., 1983. Les fosses de la Mer Rouge: approche géomorphologique d'un stade initial d'ouvertur océanique réalisée a l'aide du Seabeam. Oceanol. Acta. 6: 235-244.

Pautot, G., Guennoc, P., Coutelle, A. and Lyberis, N., 1984. Discovery of a large brine deep in the northern Red Sea. Nature, 310: 133-136.

Pautot, G., Guennoc, P., Coutelle, A. and Lyberis, N., 1986. La depression axiale du segment nord mer Rouge (de $25^{\circ} \mathrm{N}$ à $28^{\circ} \mathrm{N}$ ): nouvelles données géologiques et géophysiques obtenues au cours dela campagne Transmerou 83. Bull. Soc. Géol. Fr., 8: 381-399.

Ries, A.C., Shackleton, R.M., Graham, R.H. and Fitches, W.R., 1983. Pan-African structures, ophiolites and melange in the Eastern Desert of Egypt: a traverse at $26^{\circ} \mathrm{N}$. J. Geol. Soc. London, 140: 75-95.

Roeser, H.A., 1975. A detailed magnetic survey of the southern Red Sea. Geol. Jahrb., 13: 131153.

Rosendahl, B.R., 1987. Architecture of continental rifts with special reference to East Africa. Ann. Rev. Earth Sci., 15: 443-503.

Schmidt, D.L., Hadley, D.G. and Stoeser, D.B., 1979. Late Proterozoic crustal history of the Arabian Shield, southern Najd province, kingdom of Saudi Arabia, evolution of mineralization of the Arabian-Nubian Shield. King Abdulaziz Univ. Inst. Appl. Geol. Bull., 3: 41-58.

Searle, R.C. and Laughton, A.S., 1981. Fine-scale sonar study of tectonics and volcanism on the Reykjanes Ridge. Oceanol. Acta, 1: 5-13.

Searle, R.C. and Ross, D.A., 1975. A geophysical study of the Red Sea axial trough between $20.5^{\circ}$ and $22^{\circ} \mathrm{N}$. Geophys. J. R. Astron. Soc., 43: 555-572.

Shackleton, R.M., Ries, A.C., Graham, R.H. and Fitches, W.R., 1980. Late Precambrian ophiolite melange in the eastern desert of Egypt. Nature, 285: 472-474.

Sherman, S.T., 1978. Faults of the Baikal rift zone. Tectonophysics, 45: 31-39.

Steckler, M.S., 1985. Uplift and extension at the Gulf of Suez -Indications of induced mantle convection. Nature, 317 : 135-139.

Steckler, M.S. and Ten Brink, U.S., 1986. Lithospheric strength variations as a control on new plate boundaries: examples from the northern Red Sea region. Earth Planet. Sci. Lett., 79: $120-132$.

Steckler, M.S., Berthelot, F., Lyberis, N. and Le Pichon, X., 1986. Tectonic evolution of the Gulf of Suez rift in a regional context (abstr.). Eos, Trans. Am. Geophys. Union, 67: 378 .

Stern, R.J., 1981. Petrogenesis and tectonic setting of late Precambrian ensimatic volcanic rocks, Eastern Desert of Egypt. Precambrian Res., 16: 195-230.

Stern, R.J., Gottfried, D. and Hedge, C.E., 1984. Late Precambrian rifting and crustal evolution in the northeastern desert of Egypt. Geology, 12: 168-172.

Sultan, M., Arvidson, R.E. and Sturchio, N.C., 1986. Mapping of serpentinites in the Eastern Desert of Egypt by using Landsat thematic mapper data. Geology, 14: 995-999.

Sultan, N. and Schut7, K., 1984. Cross faults in the Gulf of 
Suez area. Egyptian General Petroleum Corp., 7th Explor. Sem., 14 pp.

Swain, C.J., 1976. Some gravity results from the northern Gregory rift: In: A. Pilger and A. Rösler (Editors), Afar between Continental and Oceanic Rifting. Schweizerbart, Stuttgart, pp. 120-125.

Talwani, M., Konig, M. and Houtz, R., 1979. The crustal structure and evolution of the area underlying the magnetic quiet zone on the margin south of Australia. In: J.S. Watkins, L. Montadert and P.W. Dickerson (Editors), Geological and Geophysical Investigations of Continental Margins. Am. Assoc. Pet. Geol., Mem., 29: 151-175.

Tewfik, N. and Ayyad, M., 1982. Petroleum exploration in the Red Sea shelf of Egypt. Egyptian General Petroleum, Corp., 6th Explor. Sem., 30 pp.

Tramontini, C. and Davies, D. 1969. A seismic refraction survey in the Red Sca. Geophys. J.R. Astron. Soc., 17: 225-241.

Tweto, O., 1979. The Rio Grande Rift system in Colorado. In: R.E. Riecker (Editor), Rio Grande Rift: Tectonics and Magmatism. American Geophysical Union, Washington, D.C., pp. 33-56.

Watts, A.B., 1981. The U.S. Atlantic continental margin: subsidence history, crustal structure and thermal evolution. In: Geology of Passive Continental Margins. Am. Assoc. Pet. Geol., Educ. Course Note Ser., 19: 2-1-2-75.
Watts, A.B. and Steckler, M.S., 1979. Subsidence and eustasy at the continental margin of eastern north America. In: $M$. Talwani, W. Hey and W.B.F. Ryan (Editors), Deep Drilling Results in the Atlantic Ocean: Continental Margins and Paleo-environment. American Geophysical Union, Washington, D.C., pp. 218-234.

Watts, A.B. and Steckler, M.S., 1981. Subsidence and tectonics of Atlantic-type continental margins. Oceanıl. Acta, 4: 143-153.

Wernicke, B., 1981. Low-angle normal faults in the Basin and Range province: nappe tectonics in an extending orogen. Nature, 291: 645-648.

Wernicke, B., 1985. Uniform sense normal simple shear of the continental lithosphere. Can. J. Earth Sci., 22: 108-125.

Whiteheand, S.A., Dick, H.B. and Shouten, H., 198.4. A mechanism for magmatic accretion under spreading centers. Nature, 312: 146-148.

Whitmarsh, R.B., Avedik, F. and Saunders, M.R., 1986. The seismic structure of thinned continental crust $n$ the northern Bay of Biscay. Geophys. J. R. Astron. Soc., 86: 589-602.

Zorin, Yu. A. and Rogozhina, V.A., 1978. Mechanism of rifting and some features of the deep seated structure of the Baikal rift zone. Tectonophysics, 45: 23-30. 